\title{
Colombia: un archipiélago biológico
}

\author{
Luis María Murillo Quinche
}

Rev. Acad. Colomb. Cienc. Ex. Fís. Nat. 1951, 8: 409-431.

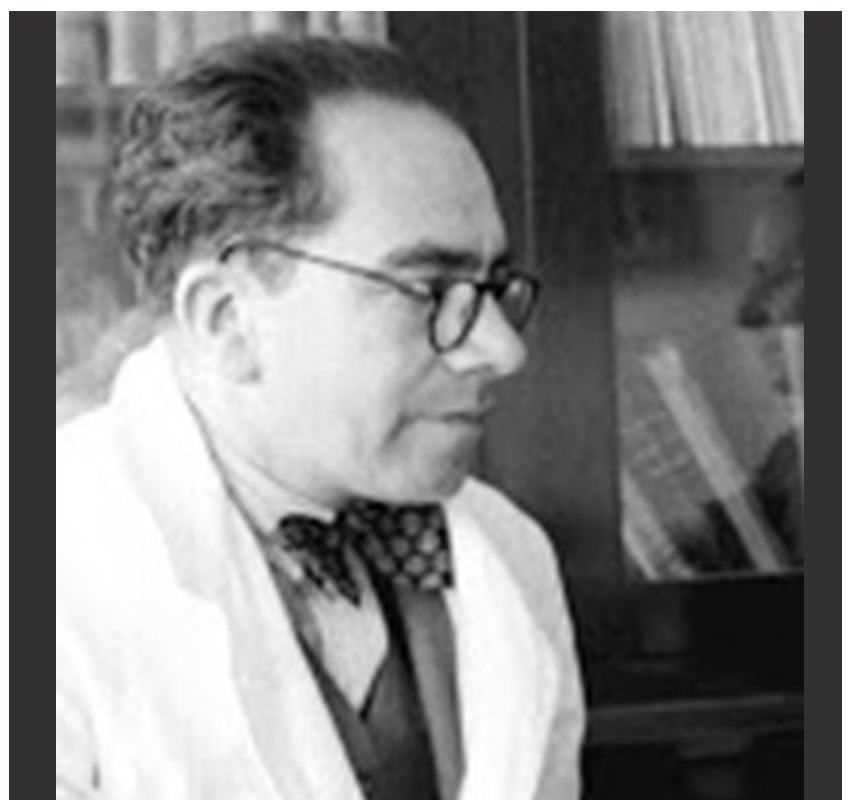

Esta publicación del año 1951 consiste de dos partes: una introducción al tema por el Doctor Luis M. Murillo (p. 409-411) y un texto original del General de la República Francisco Javier Vergara y Velasco, nacido en Popayán en 1860 y fallecido en 1914 en Barranquilla. Este texto (p. 411-431) fue tomado de la Nueva Geografía de Colombia (1888).

Los tres mapas de Colombia incluidos en el texto me llamaron la atención porque me hicieron recordar la publicación de Thomas van der Hammen en el Journal of Biogeography en 1974. Thomas publicó también dos mapas de Colombia simulando el Pleniglacial y el Holoceno. Los Andes se ven como islas grandes con mucha conexión entre páramos y bosques (Pleniglacial) y como islas pequeñas destacando el aislamiento entre estas islas (Holoceno). Los mapas de Thomas son clásicos también, pero hoy día ya se presentan más detalles (p.ej. con la evolución de los frailejones estudiado por Mauricio Diaz granados y Jesus Mavarez). Suzette Flantua \& Henry Hooghiemstra (2017) muestraron el 'flickering' del sistema durante las más de 20 épocas glaciares que han pasado por las cordilleras colombianas. La dinámica de las capas de nieve y los páramos han causado esta enorme fitodiversidad de alta

\section{Luis María Murillo Quinche (1896-1974)}

Desde muy joven Luis era muy interesado en la biología y tenía entre sus maestros los conocidos botánicos Santiago Cortés y el hermano Apolinar María. Ha leído en esta época ya mucho, entre otras la obra de Francisco Vergara y Velasco. Empezó con el estudio de insectos como prácticamente autodidacto. Terminó el bachillerato en 1917.

Como profesional se dedicaba al control de las plagas agrícolas; dirigió el Servicio de Entomología del Ministerio de Agrícola y luego la Subdirección del Instituto de Ciencias Naturales de la Universidad Nacional. Reunió una colección de más de 100.000 insectos.

Era miembro, entre otras, de la Sociedad Geográfica, de la Academia de Ciencias Naturales y esta de la Historia de Colombia; además de otras Academias en el exterior. En 1962 recibió el Orden de Boyacá. Su hija, Maria Teresa, ocupaba hasta hace poco su silla 14 en la Academia.

Luis era un científico de la entomología aplicada 'avant la lettre'.

montaña de hoy día. la diferencia en tiempo entre los mapas de Vergara y Velasco y estos de Van der Hammen son 186 años. Curiosamente Vergara y Velasco no han discutido estos mapas en su texto. El trabajo de Murillo \& Vergara y Velasco tiene un lazo interesante para la ciencia de hoy día por el concepto de ‘archipiélago biológico’ (Murillo) y los tres mapas (Vergara y Velasco).

En el texto de Vergara y Velasco cado uno podría encontrar según su interés datos interesantes. Me llamó la atención como botánico ya la división de la flora en tres grupos: boreal, (neo-)tropical y austral, 91 años antes de mi estudio (Cleef 1979).

Antoine Cleef, Ph. D.

Miembro Correspondiente

\section{Referencias}

Cleef, A.M. 1979. The phytogeographical position of the neotropical vascular páramo flora with special reference to the Colombian Cordillera Oriental. In: Larssen, K. \& Holm-Nielsen, L., (eds.) Tropical Botany, pp. 175-184. Academic Press. London-New York.

Van der Hammen, T. 1974. The Pleistocene changes of vegetation and climate in tropical South America. J. Biogeogr., 1: 3-26.

Vergara y Velasco, F.J. 1888. Nueva Geografía de Colombia. Bogotá. 


\title{
COLOMBIA, UN ARCHIPIELAGO BIOLOGICO LAS REGIONES NATURALES DE COLOMBIA
}

\author{
POR F. J. VERGARA Y VELASCO
}

Documentos recopilados y comentados por LUIS MARIA MURILLO

Nunca llegué a definir mejor el sentido de la patria, como cuando las páginas de la "Nueva Geografa de Colombia escrita por Regiones Naturales", del General de la República Vergara y Velasco, iban mostrándome su imagen retratada en más de trescientas xilografías, quizá deficientes desde el punto de vista artístico, pero colmadas de acierto técnico, de afecto $y$ de sinceridad. Entonces fueron las manos inexpertas de un niño las que voltearon las páginas del libro con torpeza y sugestiva curiosidad. Ahora, maduras y prudentes, siguen repasando las mismas páginas, que han estropeado las incesantes consultas y el tiempo ha amarilleado, sin que pueda cambiárselas por otras, pues que hasta hoy no hay obra alguna que pueda suplirlas, ni por la amorosa elaboración, ni por la sabiduría atesorada, palmo a palmo, por entre la maraña, por las vertientes escarpadas, llegando hasta las infernales hoyas ardientes, o trepando a las cimas heladas de los páramos.

La "Nueva Geografía" fue obra de larga gestación, y en forma alguna tomada de Reclus, como alguna vez lo insinuara el profesor. Pablo Vila; en efecto: el $\mathrm{S}$ de octubre de 1888 , es decir, varios años antes de que el geógrafo francés escribiera su capitulo sobre Colombia, le manifestaba éste a Ver. gara $\mathrm{y}$ Velasco, lo siguiente: "Estoy reconocidísimo por el envío que me ha hecho. La Nueva Geografía de Colombia me será de grande utilidad y de. antemano me deleito con el pensamiento de estudiarla". Se trataba de la primera edición de la "Nueva Geografía de Colombia", inserita el 9 de febrero de 1888 en el Ministerio de Instrucción Pública, para garantizar la propiedad literaria. La segunda edición es de 1892 , y la tercera, que el autor señala como la primera oficial (las dos primeras fueron costeadas por el autor), salió profusamente ilustrada en 1901, de la "Imprenta de Vapor" de Bogotá.

Aunque de esa primera edición, muy anterior a los trabajos de Reclus sobre nuestro país, no tengo ningún conocimiento dirscto, podemos informarnos del carácter de su contenido, por un memorial dirigido al Ministro de Guerra, en 1902. por el general Vergara y Velasco; dice lo siguiente: "En 1888. y con recursos propios, emprendí la publicación de una Nueva Geografía de Colombia por el Sistema de Regiones Naturales, que fue bien recibida por el público..."
En la "advertencia preliminar" que el general escribió para su última edición, nos da una idea del estado de la geografía en América, y de la original importancia de su contribución: "Y no por vanidad personal - dice-, sino por bien entendido orgullo patrio, podemos afirmar que esta edición ilustrada de la Geografía de Colombia, no tiene par en la América Latina, y deja muy atrás cuanto en la materia se conoce de México a Chile y la Argentina; y si las ilustraciones no son perfectas desde el punto de vista artístico, en cambio constituyen una obra sencialmente nacional, ejecutada por jóvenes formados en la Escuela de Grabado, en maderas recogidas en las magníficas selvas colombianas".

Fue Vergara y Velasco, militar desde su mocedad, escritor $y$ periodista por herencia, maestro siempre, e historiador, naturalista y fisiógrafo por una inclinación entrañable por su patria, y que debió tener por acicate ese bellísimo y sensual panorama colombiano. El sabio médico y naturalista Juan de Dios Carrasquilla, quien le hizo su colaborador en el Instituto Nacional de Agricultura en 1880 y 1888 , debió orientar las inclinaciones de su joven colega por los campos de la climatología, la hidrografia y la geomorfología; es decir: de la geografia física, de la cual dejara una obra original, no superada todavía. Su estilo, muchas veces lírico, descubre los lazos que le unen a José María Vergara y Vergara, el donairoso literato, hermano de su padre, que supo loar los elementos de la naturaleza con el amor de Francisco de Asís, y con toda la bizarria de su caudal poético.

Si quisiéramos juzgar la obra científica de Vergara $\mathbf{y}$ Velasco por algún testimonio valedero de la época, nos bastaría recurrir al del famoso y mundialmente renombrado geografo Eliseo Reclus; veamos algunos aspectos de su correspondencia con su colega colombiano:

A principios de 1889 - por ejemplo- le escribía : "Esto que me dice de sus proyectos relativos al estudio completo del suelo y del clima colombianos puede hacernos esperar una obra grandiosa, $y$ por mi parte, sería feliz yo de poder contribuír a su plan, así fuera en infinita proporción". Estos estudios proyectados por Vergara y Velasco fueron incluídos en la segunda edición de su "Nuera Geografia", y citados profusamente por Reclus en su extenso capítulo "Colombia", escrito más tarde. 


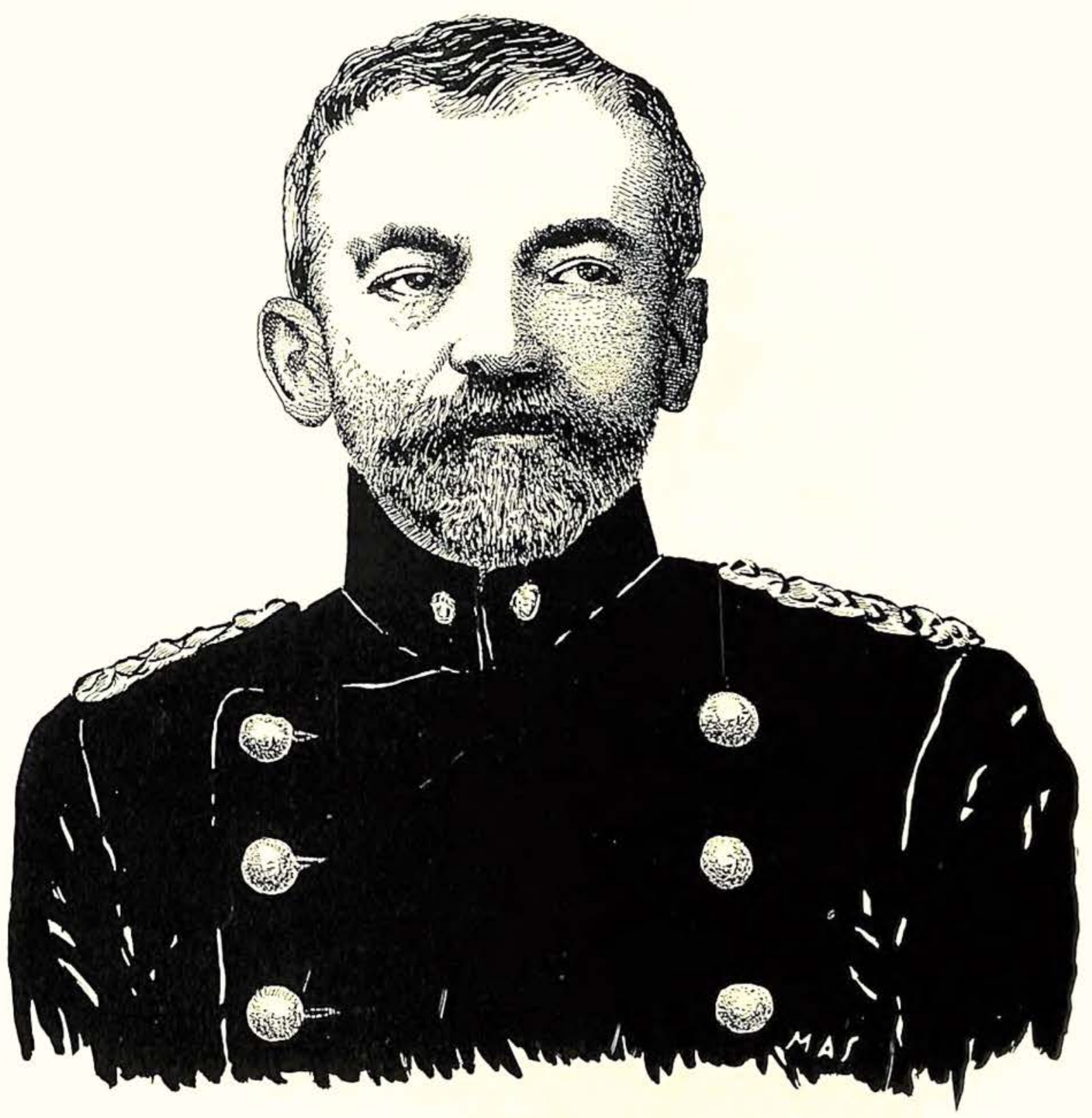

General de la República Francisco Javier Vergara y Velasco. Nació en Popayán el 15 de junio de 1860 ; murió en Barranquilla el 21 de enero de 1914. 
En los términos de la siguiente carta, firmada en 1893, está expresado, de relieve, el valor del discernimiento científico de Vergara y Velasco, puesto en duda por el ya mencionado profesor Vila: "Lo felicito vivamente por su excursión a la cima del Sumapaz y a las vertientes del Ariari; usted ha realizado preciosas investigaciones que contribuirán al progreso de la geografía. Si usted me lo permite, comunicaré el resultado de sus estudios a algunas sociedades de sabios, a menos que usted quisiera hacerlo personalmente". El final de esta carta - que muestra la profunda consideración cien. tífica que el sabio francés tenía por nuestro geógrafo, , que da testimonio, a la vez, de la ética profesional y de la nobleza de Reclus, muy diferentes de las que se hicieron patentes a Caldas por Humboldt-. dice lo siguiente: " su traducción comontada y corregida (se refiere a su capítulo "Colombia"). me parece admirable. En esta obra de colaboración es usted el maestro, puesto que sabe mucho más. Sin embargo, no es esta nna razón para que yo le dé ese título dado mi carácter igualitario, pero sí para que me satisfaga con ese otro muy distintamente precioso de amigo. Cordialmente suyo Elisée Reclus".

Era tan grande la cultura de Vergara y Velas. co, que se hizo popular; y tan múltiples sus facetas, que of recieron asidero a todas las bellaquerias. Ia envidia, esa liana amarilla que caracteriza cierto aspecto de nuestra raza, pudo treparse $y$ enroscarse a su personalidad hasta hacerlo aparecer como In "científico charlatán".

Refiriéndose a uno de esos comentarios malérolos e irreflexivos que suelen llamarse de crítica, Jorge Roa. el distinguido hombre público. le escribía. desde Londres, al general: "Fsto me ha causado tanta mavor extrañeza, crianto he visto con especial satisfacción en los centros europeos apreciar los trabaios geográficos de usted. de una manera altamente lisoniera para el orgullo patrio. Cuando esto sucede en el mundo intelectual en que hay jue. ces de vasta competencia, desconsolador es saber ane hubo notas de escasa apreciación de las labo. res de usted. Esto podría tacharse de ridículo. si no fuera más bien uno de tantos síntomas de nues. tro nohre carácter nacional".

$\mathrm{Y}$ ese ciudadano admirable, escritor e ingeniero nue se llamó Miguel Triana, escribía: "Puede asegurarse, sin riesgo de equivocación, que no hay nanel público. de veinte años al presente, que no contenga alqún escrito ritil del laborioso investi carlor. La emulación impotento le hizo ridícula mofa. pero sus obras turieron eco al otro lado del océano. v un sabio de reputación mundial (Reclus) Je tendio hidalgamente el laurel de la gloria".

Dice el profesor Pablo Vila en su "ensayo" que llamó "Regiones Naturales de Colombia" (1), refiriéndose a la obra fisiográfica de Vergara y Velas.

(1) Publicaciones de la Revista "Colombia". de la rontralo. ría cieneral de la Republiea. co: "Su autor se dejó conducir muy exclusivamen. te por la topografía $y$ la hidrografía. Los factores climáticos y las actividades humanas son tenidos poco en cuenta..."

Ya ture oportumidad de criticar al señor Vila por sus inaceptables y ligeras apreciaciones; primero, con mi intervención ocurrida en el Teatro Colón, en una de sus conferencias sobre sus "regiones naturales", cuando olvidó citar a muestro fisiógrafo, y, un año más tarde (1944), por medio de unos "comentarios científicos" que publiqué en la página editorial de "El Tiempo", y que eran una crí. tica, quizá un algo irónica a falta de espacio para un severo análisis, de su "ensayo" escrito.

Vergara $y$ Velasco hizo de los estudios de la geo. grafía física de Colombia, una disciplina de toda su vida. La sola publicación de sus obras cubre un espacio de más de veinte años densamente trabajados, no desde un escritorio y tomando sus cono. cimientos de una biblioteca, sino de torlo el terri. torio, hasta de los más recónditos parajes de la república. Su obra fue de análisis y de síntesis; de disección y de composición. La ordenación realizada por primera vez de las alturas, es el paso inicial de este proceso: él las contempla como una función del clima $y$ de la vida. Viene luégo el es. tudio comparativo del relieve contemplado en todos sus perfiles y llanuras; después el análisis de ese origen orográfico que morleló las hoyas hidrográ. ficas, dio curso a los vientos $\mathbf{y}$ formó los microcli. mas. Su estudio climatológico es una interpreta. ción genial sobre el cual se desenvuelve la flora y la fauna. Finalmente, después de todo este complejo estudio escrito en más de cuatrocientas bien nutridas páginas, entra a describir las regiones naturales de Colombia, en una suerte de deducciones lógicas y que ocupan trescientas págrimas más.

Las comarcas o regiones naturales de Vergara y Velasco son, en consecuencia. producto de m examen rigurosamente científico, que se teshorda de ese monumental volumen de su "Nueva Geo. grrafía".

Quisiera que los lectores confrontaran con esta obra, la versión que de ella da el señor Vila, y con las "regiones naturales" del mismo profesor. De esta manera deducirían por sí mismos, de si a nuestro fisiografo "le faltó sn método", como dice el pro. fesor español, o si, por el contrario. fue dueño de uno maravilloso, el de la observación personal e inteligente realizarla por todo el territorio colom biano $y$ luego vertida en ordenadas $y$ sabias conclusiones no exentas de errores, pero, en todo caso. originales y honradamente expresadas. Las consul. tas bibliográficas eran insignificantes $y$ el plagio imposible.

Pero en dondle el señor Vila resulta más censurable, es en el haber recogidlo en sus escritos los mis. mos elementos que sirvieron al ambiente ignorante y mezquino que rodeó al General, para renovar 
la predisposición de las gentes hacia su magnífica y valiosa obra, no superada hasta ahora, y que ha servido de permanente consulta a autores nacio. nales y extranjeros, aunque algunos hayan olvidado citarla en sus bibliografías como, me parece, debió sucederle al gran biólogo Frank Mr. Chapman.

Hay en la obra Dostojevskiana un personaje bueno como un ángel, ingenuo y manso como un idiota. Esta criatura endeble, torpe y pusilánime, que narlie quiere tomar en serio, de la cual se rien todos $\mathrm{y}$ que no entiende esa vida cotidiana del Fomo lupus disfrazado eternamente de oveja, es el Príncipe Muiskin. "el idiota", el hombre de sentimentalidad de niño.

Pero de otro modo, ese Príncipe dice cosas que muven a la meditación, que no entienden los demás, que conmueven, que son geniales y que él extrae de su alma, como Platón debió concebir el nacimiento de las ideas primas en la concepción de su teoría intuicionista. Este extraño comportamiento de Muiskín, lo genera su "inteligencia prinripal”. esa extıaña inteligencia de los genios, generalmente torpes para la intriga, incapaces ante la lucha cotidiana de la vida.

Troyat, el mejor de todos los eríticos-biógrafos de Dostojerski, da ma grande importancia a esta "incursión de la inteligencia principal en el dominio de la inteligencia secundaria", pero, infortunadamente, deja su concepto en la superficie, sin ahondarlo, y es lástima, porque "El Idiota" es la no. vela más difícil de leer, pero la más grande del más genial de los escritores rusos.

Esa inteligencia principal y esa otra secundaria, son dos factores enlazados como en esa fórmula eléc. trica de Joule: dado un poder total del entendimiento, éste se convierte en una función de la inteligencia principal o genial combinada con el vaolr de la secundaria o de la vida práctica. Estos dos factores se encuentran, pues, en una relación inversa.

Este discurso que parece alejarme del tema, me sirve, en realidad, para destacar mejor el carácter de Vergara y Velasco, y quizá el de muchos hombres que por poseer una genial inteligencia, no pudieron contar con una práctica propicia a las artimañas $y$ a la incrementación de esos elementos que hacen fácil y muelle y colmada de simulaciones la vida.

Se presenta, a continuación, el capítulo de la "Nueva Geografía de Colombia": "Climatología"; en el próximo número se publicará el capítulo "Aspecto Físico", que comprende, propiamente, las Regiones Naturales de Colombia.

\section{LIMATOLOG IA}

Si por clima entendemos el conjunto de las conriciones atmosféricas que afectan los órganos de los seres organizados, evidente será que depende de múltiples causas que pueden reducirse a tres: temperatura, vientos, humedad, siendo su variada combinación la que en cada zona o región hace que el clima se presente como una entidad distinta e importantísima, por así decir. Desde este punto de vista, es claro que el clima de Colombia, abarcado el país en su conjunto, es esencialmente tropical, es decir, cálido, húmedo y batido por el alisio; pero

(1) Como el calor del centro del globo. sl existe, no tiene in. fluencia sobre la superficle, el calor de ésta províene de la irra. diación solar, cuyn eantldad para un lugar dado depende de su latitud o inclinación de sul horizonte con respecto al ceuador, por lo cual la temperatura disminuye de la equinoceial hacia el polo lo cual la temperatura disminuse de la equinoceial hacia el polo
$y$ del medio día hacia ln media noche: por esto es la latitud media $\left(45^{\circ}\right)$ ln que ofrece variaciones más rápidas en el calórico.

Mas, esto no es todo: la temperatura también baja a medida que nos lovantnmos sobre el nivel de los mares, por euanto queda más y más lejano el reflector: pero esta disminución es variable. yn que su uniformidad quedará rota por las corrientes de aire. frías a calientes, propias de cada zona. Con todo, $y$ como mera nproximacion, puede decirse que la temperatura disminuye $1^{\circ}$ con cada 180 metros de altitud, lo cual expliea por que en los trópiens lns montañas producen como otro mundo superpuesto al natuml $y$ puele llegarse en breve espacio hasta el elima mismo de la region polar.

Fn resumen, la temperatura resulta de la latitud, de la altitud, de la direceión de los vientos $y$ de la configuración del suelo; el trazo de las líneas isotermas, isoteras e isoquímenas resume la media de las variaclones anuales, bien que el examen de las produeciones naturales del suelo sea el sistema de apreciación más exacto. El calorico del aire, aunque no basta a earacterizar un clima. forma la base de este y resume las condiclones que ayudan a constituíle. Las medias diurnas $y$ anuales son, por lo mismo, clemento de información indispensable. si con el conjunto se miran las partes, si se opone la llanura, donde aquellos tres elementos imperan sin contradicción, a la montaña, que los restringe y complica, entonces la frase climatología colombiana no puede emplearse sino en un sentido muy especial. En efecto, el occidente colombiano por su variado relieve, por sus cadenas y macizos, por sus terrazas y sus mesas, ofrece tan grandes contrastes. que posee toda la serie de los climas, los cuales entrecruzan diversamente sus curvas del día a la noche $y$ de una estación a otra (1). Cada valle, cada

Empero, la vida no es s6lo calor, también es luz, y la ríqueza de la vegetación depende en mucho de tal elemento. por lo cual esta ligada al clima en que vive. No sucede lo mismo con los animales aue, puede decirse, viven con el calor $y$ la luz que han

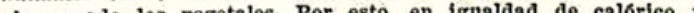
nimacenalo los vegetales. Por esto. en imualasd de calorico demf́s condiciones, los regetales legan más rápidamente a la madurez $y$ viven mejor bajo un cielo sereno $y$ brillante. que bajo nno cubierto $\mathrm{n}$ opaco: prueba. los valles del alto Magdalena. $y$ el Canca. El calor es necesario para que la planta asimile $y$ crezen : in irradiación solar es indispensable para la formacion del fruto.

La fluminacion de un lugar varfa poco con la latitud o la altitud, mientras que in temperatura to hace en sumo grado con ambas condiciones: mientras la reparticion de luz difiere a partir del ecuador (donde es casi siempre ln misma) con la altitud $y$ la latitud que la hacen írregular segûn el mes. En ciertos puntos crecen plantas con poco calor, con tal que no falte la luz: se da 1n ceba en nuestros yermos páramos cuando en el verano el cielo se conserva limplo, $y$ la papa madura mal en zonas algo inferiores pero nebulosas de ordinario; por 10 mismo. en elimas inferiores pero nebulosas de ordinario; por lo mismo, en climas por la razon inversa to hace en elevadas y frias mesas. Lo dicho por a de los vegetales se refiere también al animal $\mathrm{y}$ al hom bre, sunque en menor grado.

Las Ifneas isotermas (igual temperatura media) en el trópico no varfan sino con la altitud, pero distan mucho de ser paralelas entre si; suben y bajan de modo vario a lo largo de las faldas 


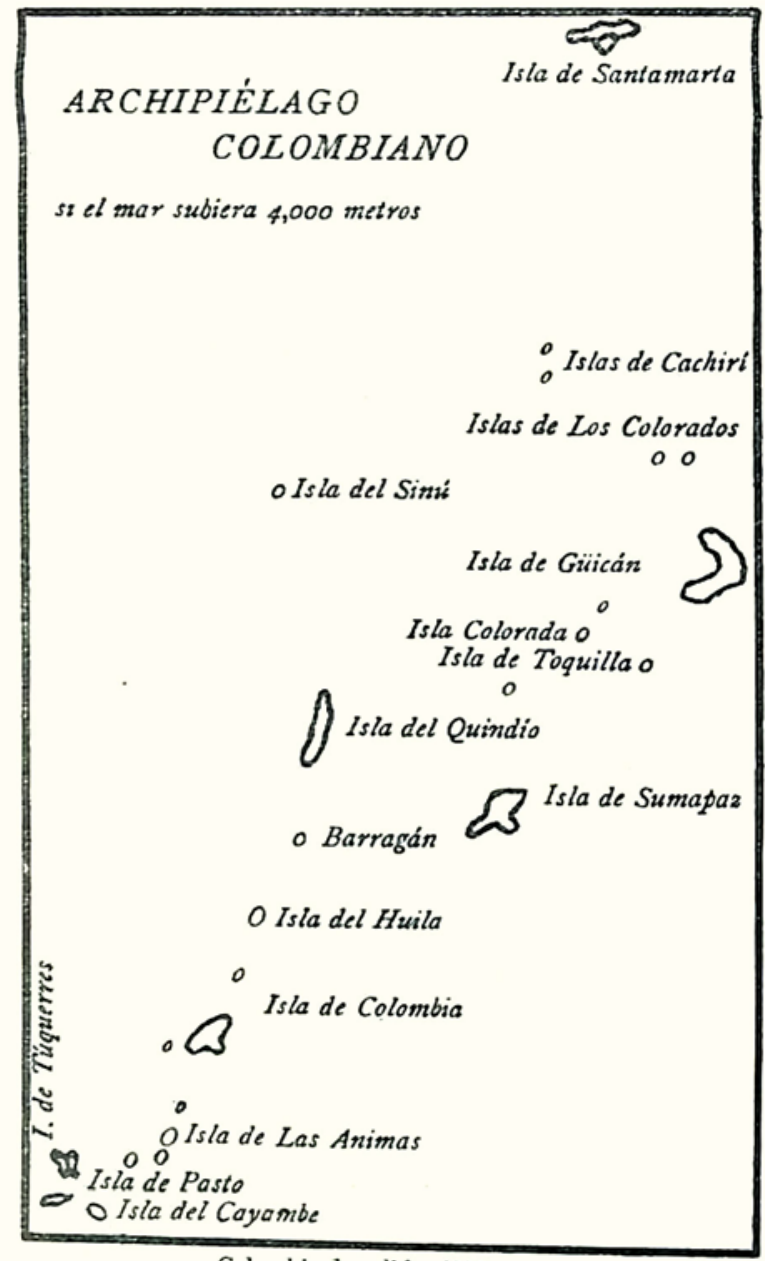

Colombia hundida 4000 metros.

de las cordilleras; de ahi los grandes errores que se han escrito sobre cllas, consideradas en Colombla: más dista el Perú del ecuador $y$ más aito principia alli el nivel de las nleves perpetuas. Las isoquimenas (igual temperatura de invierno) y las iscteras (id. en estío), poca aplicación hallan aqui, donde en cambio es preciso crearlas para la igual temperatura diaria $y$ nocturna, por todos descuidadas $y$ tan importantes en todo. Bogotá, por ejemplo, más frío que Tubará en el día, casi se le iguala en la madrugada! En general, las costas occldentales son menos cáIIdas que las orlentales y el clima medio es más suave en ambas que en el interior de las montañas; los valles más angostos son mas cállos que los mas anchos, $y$ las crestas o cumbres tanto más frías cunto más envueltas están por las bajos regiones ca. lias, debicto esto a la soln frrallaclon.

El aire que se calienta en el ecuador se eleva luego $y$ se preelpita sobre los polos (corriente ecuatorial), a reemplazar el fric que de allí corre (contracorrlente polar) hacla aquél, acercándose en el trópico al swelo, por to cual produce los allsios (vien. tos constantes) que se inclinan de E. a W. por causa de la ro tacion de la tierra. Las grandes corrientes atmosfericas se superponen o yuxtaponen $y$ en su punto de contacto surgen remoinos, causa de vientos accidentales. Por esto los lugares dos por la primera tienen mnyor temperatura que log erngados por la otra, salvo que los montes se interpengan, pues osto hacen seeo y frío todo viento oâlidio y hímedo. Por razones infon muy pequefiat) que las varlaciones en su temperatura medin Bon muy pequefiat) liace of oficlo de regulador y causa la dife rencla ontre ellmas maritimoso de regulador $y$ causa la difeaxcosivos, En fin, el mar y las constantes y continentales o les por in entos loca. costn en el dif $y$ encia de temperatura entre ellas $y$ el llano o de vaiven; de o al le la costa o el monte al mar la a orientación $y$ relación entre relieves $y$ hondonadas produce variaciones en las corrientes generales, variantes que no pueden fijarse sino tras observaciones prolongadas.

La humedad es la consecuencia del regimen pluvial unido a la prndiente $y$ permenbiliad del terreno $y$ a la faclliat de is falda, cada altiplanicie, tiene sus condiciones meteorológicas particulares, debidas al calor solar, a los vientos, a la humedad del aire y por lo mismo las grandes leyes climatéricas que riggen en los re. lieves del país no pueden indicarse sino de un modo general, prescindiendo de las mil variaciones lo cales; variaciones que se ven en el flanco de cada cordillera por el escalonamiento de la vegetación y la oposición de las escarpas desuudas y los selvosos pedestales.

Teóricamente, el ccuador térmico del globo debiera seguir al ecuador geográfico, pero p!áctica. mente cruza por cerca de nuestro litoral atlíntico, que como es refrescado por las brisas, lo rechaza un poco al sur, de suerte que si en dicho litoral la temperatura media anual oscila entre $27^{\circ}$ y $28^{\circ}$, en las llanuras septentrionales de la Magdalenia sube a $31^{\circ}$. Ambas cifras aumentan un poco donde el suelo es arenáceo y carece de vegetación. Además, esa temperatura normal de $31^{\circ}$ se acrecienta a 32 y $33^{\circ}$, si de la zona litoral pasamos a la con. tinental, o sea las llanuras de la Orinoquia y parte de la Amazonia, porque hacia la vaguadi del río de los ríos, por la facilidad con que lo baña el Alisio, disminuye otra vez a las cifras señaladas para el litoral atlántico. En tesis general, la temperatura es menos elevada en la costa del Pacífico y desciende hacia el mediodía (Tumaco $26^{\circ}$ ), por cuanto allí aún obra la corriente fría de IIumboldt. La línea que enlaza a Tumaco con el Amazonas es aún más fresca; lo propio sucede con la que cruza la cordillera de Talamanca y con la que une el Ori-

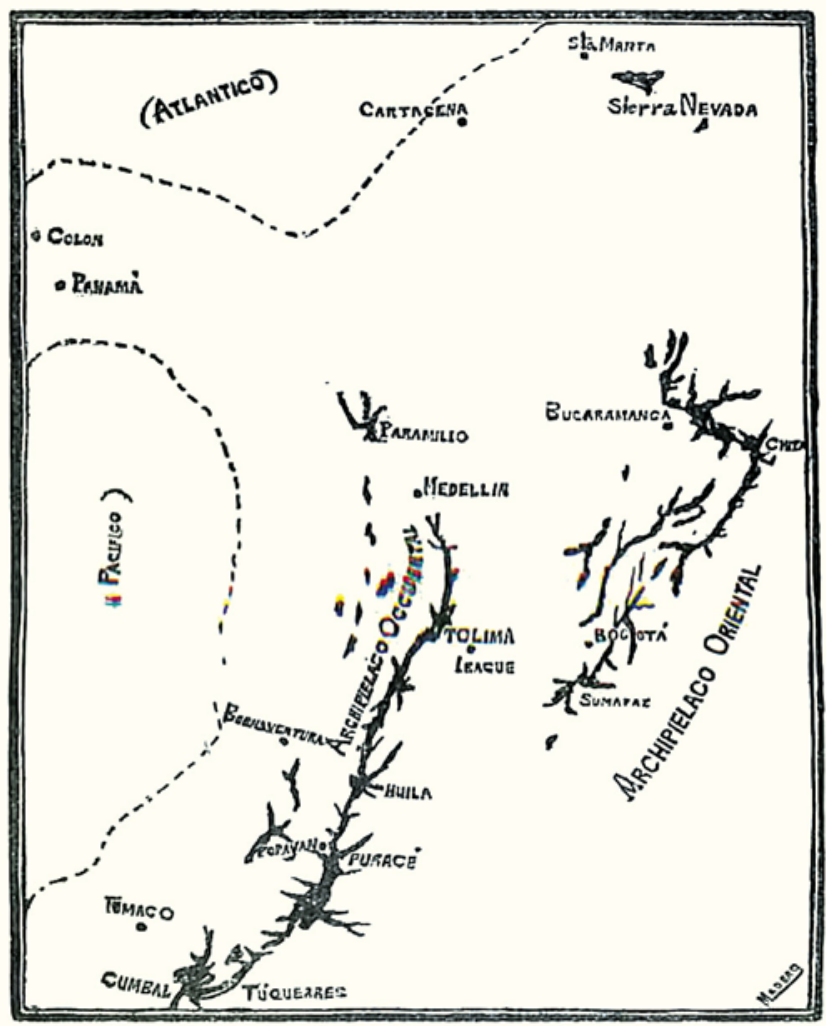

Colombia hundida 3000 metros. 
noco al $A$ mazonas. En cambio, dentro de los pliegues andinos se encuentran valles donde el termómetro marea temperaturas superiores. En una palabra, prescindiendo de las temperaturas ocasionales o de ciertos lugares en ciertos días y épocas, tendremos que Colombia (con parte de Venezuela) es una especie de isla climática, con perímetro re. lativamente fresco que enruelve un extenso núcleo más ardiente, sobre todo al E., dentro del cual, hacia el NW., surge pequeña mancha que lo es mucho menos, y que en su seno guarda, a modo de fajas, porciones en que el calor desciende hasta llegar a $0^{\circ}$ y a la vez encierra aquí y allá, por vía de contraste, como puntos, los sitios donde sube

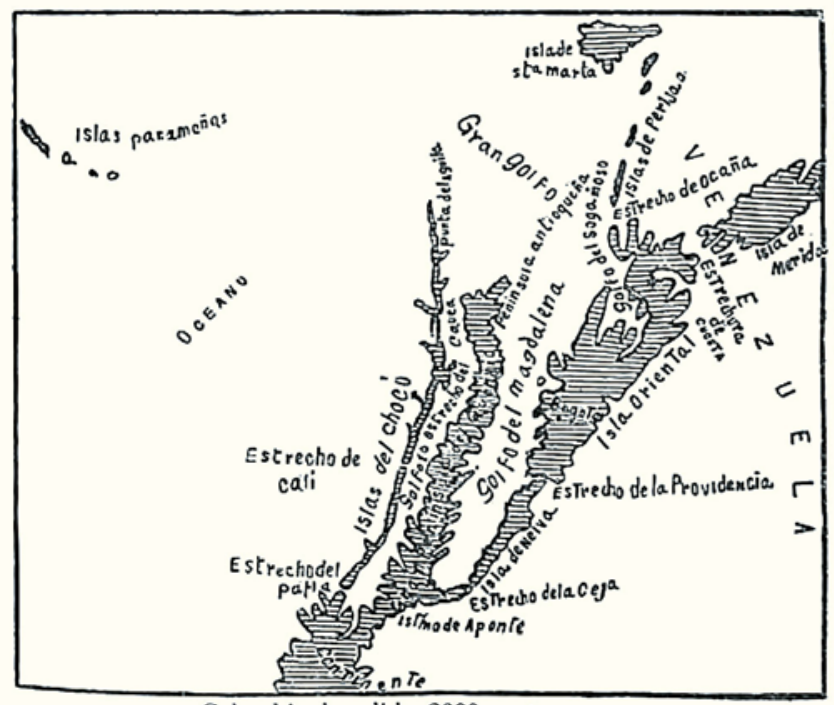

Colombia hundida 2000 metros.

evaporación: el estudio geológico del suclo da la primera idea en el asunto; el del régimen de los vientos constituye la segunda. El grado orilinario de humedad ejeree influeneia decisiva sobre el hombre $y$ su higiene. Además, las lluvins establecen el regimen de los ríos, determinan su venaje $y$ el número $y$ eaudal le las fuentes, $y$ en ciertas comareas hasta regilan la vida por su cotidiana periodicidad: la cantidad de agua que cae en cada estación es dato indispensable para fijar un clima. No es extraño ver en un rio demorado el tráfico en sequía por falta de agua y al lado suceder la inversa en las corrientes salidas de madre: los estudios pluviométricos son dificiles $y$ las medias locales están sujetas a muchas irregularidades accidentales.

Con todo, entre los trópicos, a 10 menos en las partes bajas - llanas, las lluvias siguen casi leyes matemátiens en su frecuencia $y$ periodicidac. En la región de los alisios puede decirse cuenein $y$ periodicidacl. En la región de los alisios puede decirse
no llueve jamás: el cielo se conserva puro $y$ solo de tlempo en tiempo ocurren grandes tempestades. En la de las calmas ecuatoriales llueve todos los dís: all los mismos alisios acumulan enormes cantidades de vapores que, apenas alzados, no tardan en convertirse en nubes espesas que forman anillo - pues no se resuelven del todo en lluvia- que absorbe parte del ealor solar que Intercepta, se disuelve y los vapores, dejados libres, son arrastra. dos por los contra-alisios hacia las latitudes superiores: una parte desciende de nuevo $y$ se coudenza bajo la forma de otros dos anillos de nubes que se estarionan en la región de las calmas tropicales, en los limites nustral $y$ borenl de los alisios; In otra parte es arrastracla hacia las zonas templadas por las corrientes ecuatoriales. Esto con ritmo perdurable, que según la mareha del sol predomina hacia uno u otro polo.

Pero no sucede lo mismo en las montañas donde hay grandes Irregularidades que en general dependen del paso del sol por el zenit, de la altura, de la vecindad de las costas, de la extension de los bosques $y$ del eruce de las corrientes atmosfériens.
de altura, de la vecindad de las costas, de la extens

Además, según sea la temperatura a que se produce la con. densacion, el vapor atmosferico produce lluvia o nieve. La nieve persiste todo el año en las latitudes polnres $y$ en determinatas montañas, en donde la temperatura media anual tiene que ser a lo menos igual a $0^{\circ}$. La altitud del limite de las nieves per- más el termómetro, es decir, los infiernos colom. bianos.

Todo país tiene una cxposición general que no excluye las locales. Colombia se vuelve al oriente, pero muchos de sus grandes valles se abren al norte $y$ otros lo hacen al S. o W. Una altura expuesta a $45^{\circ}$ al medio día recibirá perpendiculares los rayos del sol cuando éste se halle a $45^{\circ}$ de altura, en tanto que expuesta al $\mathrm{N}$. los rayos rasarán si superficie sin calentarla; estas diferencias sensibles en simples colinas, se hacen enormes en las grandes montañas; no es raro hallarse con una falda cu. bierta de nieve, mientras la otra, a la misma altura, sustenta jardines. Toda altura expuesta al E. es menos cálida que la que mira al ocaso; los rayos de la mañana tienen que combatir el enfriamiento de la noche sobre la cima al E., en tanto que llegan sobre el de la exposición contraria (S.) cuando ella ha recibido largo tiempo la acción del aire cálido ambiente; por esto en la sabana es mayor la temperatura de la falda en que está Bogotá que la de aquella que sustenta a Facatativá. En los valles $\mathrm{N}$. la temperatura crece con la sostenida reflexión de los rayos de una a otra banda, como lo testifican todos los de ese rumbo en los Andes, de clima su. perior a la zona en que desembocan.

El clima ejerce también considerable acción so. bre el hombre. En tanto que el habitante de suelo cálido casi puede prescindir del vestido $\mathrm{y}$ no necesita sino frugal alimentación que adquiere sin mayor esfuerzo, el de los climas fríos se halla sujeto a mayor fatiga para procurarse vestido, abrigo $\mathrm{y}$ alimentos. Nada incita al primero a salir de su inercia; todo obliga al segundo a desplegar cons-

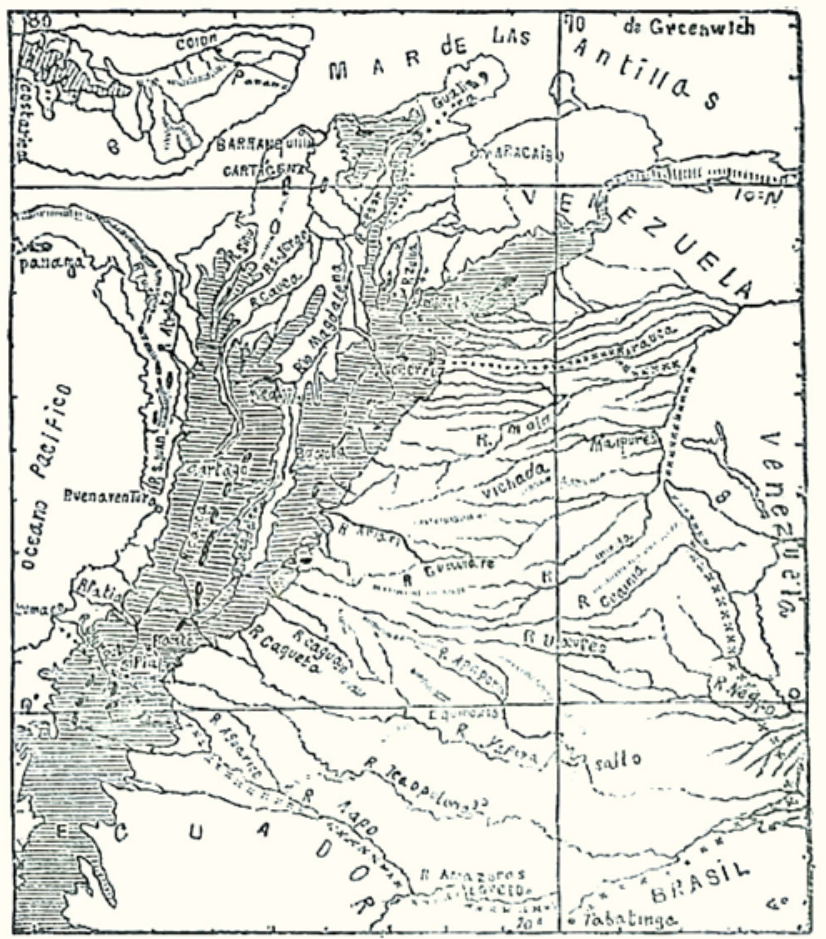

Tierras altas y tierras bajas de Colombia. 
tante actividad variando sus manifestaciones; las necesidades de aquél no cambian, las de éste aumentan sin cesar. El uno es imprevisor, se deja arras. trar por las pasiones del momento; el otro aprende pronto a dominarse, busca solaces más levantados, se hace prudente y calculador, su espíritu adquiere facultades mayores de observación y raciocinio. Análogas diferencias hay entre el montañés y el habitante del llano. En efecto, próximas están las tierras frías y calientes, y en ellas difieren usos, traje, acento, costumbres, tipo. Según Ancízar, puede pintarse así este marcadísimo contraste: "Crece el montañés o reinoso rígido y musculoso como las cumbres que se oponen a su libre movimiento; los caminos orillan precipicios y le vedan la carrera, por lo cual es grave, lento $\mathrm{y}$ acostumbra marchar en fila india; el ruido bramador de los torrentes ahoga su voz desde la infancia, lo amedrenta luego el solemne silencio de los desiertos páramos, que de ordinario cruza sólo, con gran peligro, y se hace taciturno y reservado a la vez que audaz y reflexivo, por la grandeza de la lucha diaria que debe sostener. El calentano, sobre todo el de las regio-

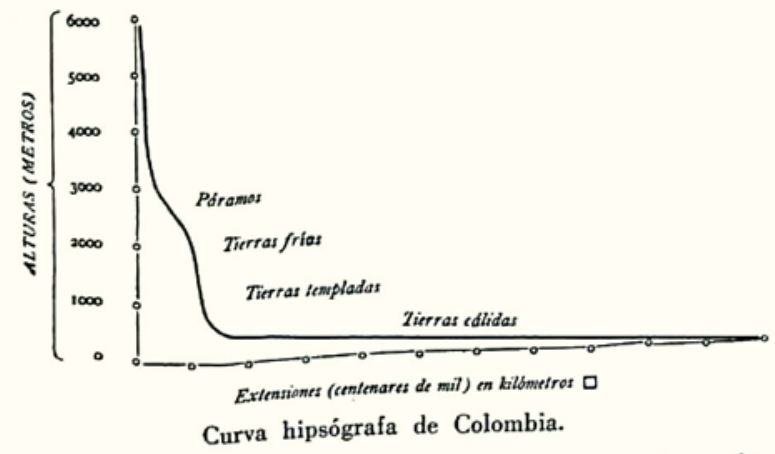

manentes depende de la situación geográfica de las cimas, de su altura, de su exposicion $y$ de la dirección general de los vientos: entre los trópicos se calcula es de 4.800 metros, pero en Colombia resulta de 4.560 a 4.650 , según su distancia al ecuador, $y$ en la vertiente expuesta a los vientos más cálidos siemdor, $y$ en la vertiente expuesta a los vientos más callaos slem-
pre se conserva unos 100 metros más alta que en la opuesta, aunque, como se comprende, hay sus variaciones locales. Pued también asegurarse que es tal lo calido de nuestro clima, que si las cimas hoy nevadas perdieran su nieve por algún cataclismo, no volverían a adquirirla: falta el centro condensador. y la estacion invernal es demasiado breve para que produzea hielo, pues el medio anual de la temperatura del aire en nuestros nevados no aleanza a $0^{\circ}$.

En fin, la naturaleza del suelo influye sobre los climas de diverso modo. Todos los terrenos no se calden con la misma rapidez; los arcillosos e impregnados de sal enfrían la atmosfera; la arena seca aumenta el calor; suelo ligero calcáreo arenoso, da en general temperatura seca y salubre; los pantanos y la arenas húmedas, disminuyen el calor; las aguas estancadas se hielan con más facllidad $y$ por más tiempo que las vivas; si el pantano se produce en elima calldo, es aún más funesto por los miasmas pestilenciales que desprende, salvo que haya corriente miasmas pestilenciales que desprende, salvo que haya corrsenter
perenne aérea, pues donde el viento sopla seguido no puede haber atmosfera impura. A su turno, aunque con lentitud, el hombre actúa poderosamente sobre el clima, que sin el cultivo es siempre más malsano que con él; su mano consigue disminuír el vigor del suelo $y$ hace habitables zonas que no lo son antes que el aire $y$ la luz lo penetren integramente.

El elima tiene Influencia considerable sobre la distribución de los seres organizados, en especial sobre ciertos animales que no pueden, como los pújaros migradores, eambiar temporalmente de patria. Por to que hace a las plantas, preciso es distingul las anuales de las arborescentes, $y$ entre estas los firboles propio de las herbficeas vivaces que resisten mejor el frío. A los cereales, por ejemplo, importa poco este, con tal que durante cierto perfodo hallen ealor $y$, sobre todo, luz sufieiente. nes llanas, no se afana ni medita en el mañana, como que los árboles le ofrecen de sobra y espontámeamente ricos frutos, los ríos fúcil y variada pesca, a la par que la caliente tierra le abruma con sus cosechas y le agobia con su calor, que no le obliga a mayores gastos en su traje y le incita a la vida muelle, perezosa, $y$, por tanto, a la sociabilidad y a mayor libertad en las costumbres, pues. to que la noche, lejos de retraerle con el frío den. tro del hogar, le llama al aire libre a buscar la suave, callada y refrescante brisa y la espléndida iluminación del cielo; canta y se hace locerar paral formar ruido donde todo es silencio y hasta las aguas murmuran apenas. Se mueve con facilidad de una parte a otra, pero se hace inconstante. confiado, imprevisor; en él lo ideal domina sobre lo real, sólo que ese iılealismo con frecuencia es más que prosaico". Quizá sobre nada obran tanto los dos climas como sobre el acento, el aseo y el amor: en tierra fría esta pasión de ordinario no echa hondas raíces y es más costumbre que otra cosa; el aseo, por desgracia es poco o ningumo y la pronunciación apretada con cierto ritmo de agua que borbota, mientras el calentano, más ardiente y muy aseado, habla con más lentitud y con cierto ritor. nelo agraciadísimo en labios femeniles.

La temperatura del cuerpo humano es poco más o menos la misma en todos los climas; en los fríos gasta enormes cantidades de calor y para reponer. las busca alimentos grasos, bebiclas alcohólicas, y la respiración es más activa, por lo cual el calentano enferma del pecho al cambiar de medio; su. cede la inversa al paramuno, cuyo hígado trabaja para separar el carbón incompletamente quemado por el pulmón. Verdad que en la montaña el hígado sufre por otras causas y por esto es la víscera más enfermiza en los climas tropicales, en clonde la anemia es endémica arriba por falta de aire $y$ abajo por exceso de miasmas; por lo dicho, también el cerebro del primero funciona mal en la montaña $\mathrm{y}$ el del segundo se fatiga muy pronto en las tierras bajas. La peor estación o clima en los trópicos es aquella en que un excesivo calor se com. bina con la humedad y estorba la transpiración cutánea, o en la montaña cuando el frío es tal y tan rápido el viento, que se paraliza la sangre en las venas. Por esto el hombre normal es el de los climas templados, no sujetos a influencias extremas y que a la vez puede plegarse a los dos; suya es, por esto, la tierra entera.

En verdad que en general no puede decirse cuál es el clima medio de Colombia, pues a más de ocu. par $12^{\circ}$ de latitud, alza tierras a muy diversas al. titudes, tierras en que mil causas modifican el clima, hasta en zonas colinclantes: sin embargo, atendiendo sólo a las áreas cálidas y húmedas, con. forme queda dicho, puede considerarse la Repú. blica como cálida y hímeda, con un apéudice frío y húmerlo. La misma montaña no es barrera mar. cadla por abrir sus valles de $\mathrm{S}$. a $\mathrm{N}$. a concluír sobre 


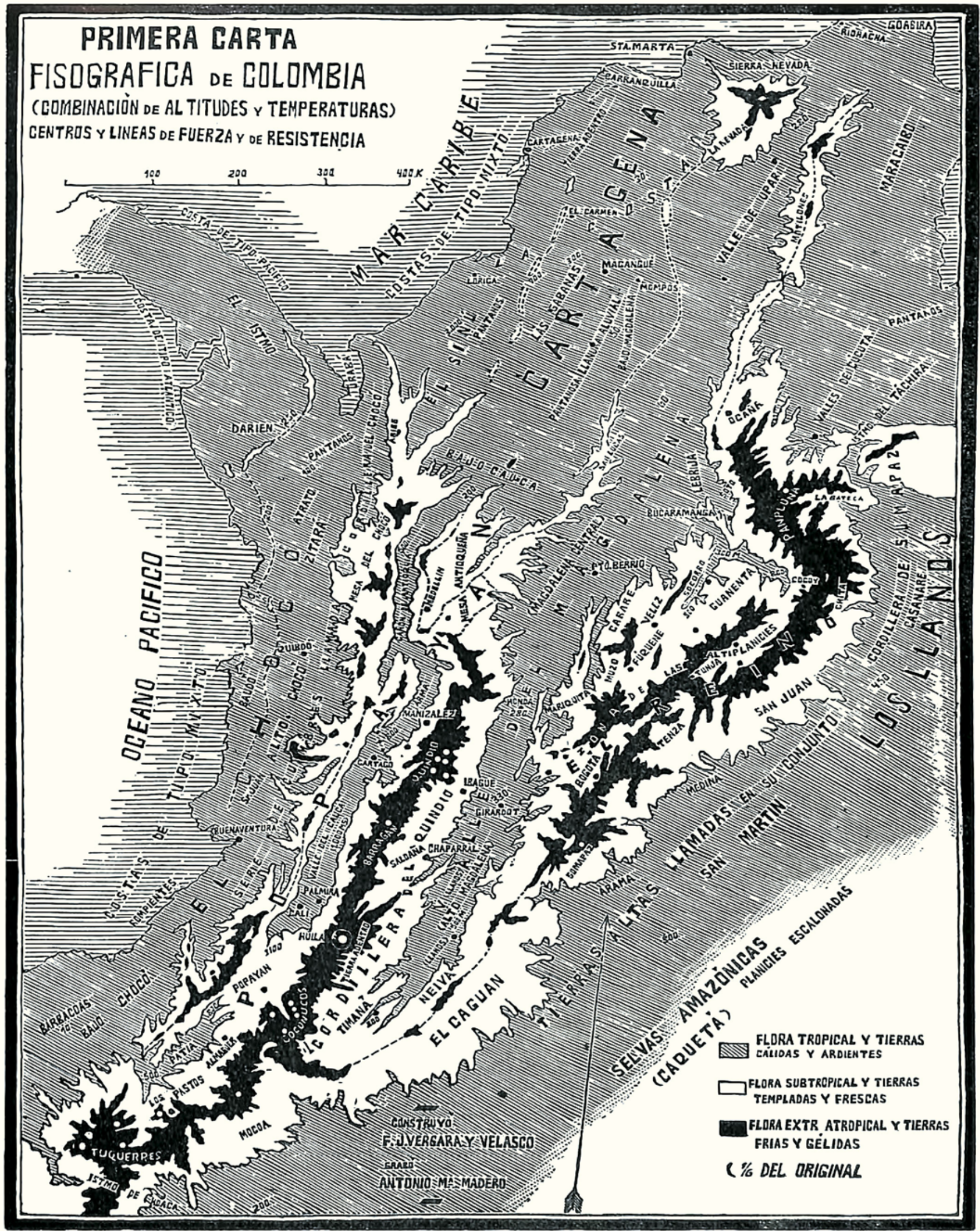

Facsímil de una de las eartas del "Atlas completo de Geografín de Colombia" del distinguido ingeniero y fisiósrafo colombiano Franciseo Javier Vergara $y$ Velaseo. Esta obra fue publieada en 1903 en un imprenta hogotana: contiene sesenta mapas xilozrafindos $y$ representa.

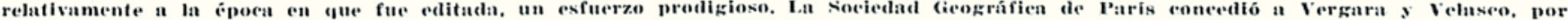
su atlas, el premio "Charles Manoir". que sólo se ha concediclo a los mayores esfuerzos eurtográficos. 
diverso mar $\mathbf{y}$ por dar libre acceso a los vientos de todo el horizonte por sus múltiples brechas.

Esto sentado, debemos pasar a consideraciones de otro orden. ¿Cuál es la temperatura media del trópico? Todo escrito sobre el asunto resultará errado si se olvida una distinción fundamental, la de los climas marítimos y la de los climas continentales. Por tanto, tendremos en el país tres puntos capitales que considerar: $1^{\circ}$, la zona marítima; $2^{\circ}$, los grandes valles interiores, y $3^{\circ}$, la llanura continental subdividida en selvosa y herbácea. Ahora bien: el término medio de las tres es 29.5 grados; pero si computamos la extensión o área de cada una de esas zonas, el guarismo no es el mismo, resultando entonces $30^{\circ} 5$, mientras el de la sola montaña es de 20 ; la de todo el país, por áreas, $25^{\circ}$. En nuestras costas, $27^{\circ} 5$ es la temperatura media, aumentada a $29^{\circ}$ en la Goajira por la refracción de la arena $y$ disminuída a 26 hacia Tumaco por la mayor frescura del Grande Océano, por lo cual también es un poco más cálida toda la costa atlán. tica que la pacífica. Los Llanos, al contrario, a a pesar de sus ríos, por falta de bosque y por estar batidos por vientos que se secan al cruzar a Venezuela, presentan en el fondo de la cuenca y en parte de las vaguadas del Meta, Casanare, Arauca y Apure, hasta $32^{\circ}-33^{\circ}$ (la cota 180 metros), sólo disminuída por causas locales; temperatura que hacia las faldas de las serranías o en los relieves del ocaso disminuyen $27^{\circ}-28^{\circ}$ (la cota 600 metros) ; algo menos al pie de la Nevada de Chita y hacia el Atabapo: el clima medio del llano es, pues, $31^{\circ}$. En el Caquetá, la selva refresca un poco la temperatura, la que oscila de $31^{\circ}$ a $30^{\circ}$ hasta los 200 metros, pero en cambio no se reduce a $27^{\circ}$ sino al rebasar los 600 metros, debido a ser el centro un saco sin salida. Cuanto a los valles interiores, tenemos que el bajo Magdalena, sin la costa, ofrece temperatura media de $29^{\circ}$, salvo hacia Sicuco, frente a Valledupar, donde sube a $30^{\circ}$, calentado por el aire de éste que llega a $31^{\circ}$ por sus arenas desnudas. Los mismos $29^{\circ}$ dominan el Mag. dalena central y el alto, en faja eso sí más y más estrecha, hasta Neiva, bien que las areniscas ayuden a tal resultado en la parte alta. La temperatura en cuestión avanza por el Cauca hasta Caceres, pero en las sabanas de Bolívar y el Sinú la templa el aire del mar, como sucede en los valles de Cúcuta, en tanto que la cuenca del Patía es refrescada hasta $27^{\circ}$ por sólo los vientos de las serranías. En los demás valles bajos de nuestras montañas el clima oscila entre $23^{\circ}$ y $26^{\circ}$, como sucede en Panamá y en las faldas del Chocó, mientras en los medios es de $20^{\circ}$ a $18^{\circ}$; en los altos y en las altiplanicies es de 10 a $15^{\circ}$, y en las crestas culminantes de 1 a $7^{\circ}$. Todos estos climas son más sostenidos en la llanura que en la montaña, y de ahí la infinita riqueza y hermosura de ésta a cierta altitud; en efecto, como Colombia es tierra tropical, su temperatura sólo varía con la altitud, bien que ésta se modifique de un modo extraordinario con la exposición, la humedad, la vegretación, la amplitud de los valles, la estación, los vientos $\mathrm{y}$, sobre todo, con las depresiones $\mathrm{y}$ alturas vecinas, pues aquéllas dejan pasar aires de otros puntos diferentes en temperatura y éstas enfrían el suelo tendido a sus pies.

Graves inexactitudes se han escrito sobre la temperatura de Colombia. Antes se calculaba que de 0 a 1.000 metros la temperatura media ascendía a $25^{\circ}$ (máximo, $39^{\circ}$; mínimo, $18^{\circ}$ ); de 1.000 a 2.000 a $21^{\circ}\left(30^{\circ} \mathrm{y} 12^{\circ}\right)$; de 2.000 a 3.000 a $18^{\circ}\left(24^{\circ}\right.$ a $\left.1^{\circ}\right)$; de 3.000 a 4.000 a $7^{\circ}\left(20^{\circ}\right.$ y $\left.0^{\circ}\right)$; y de 4.000 a 5.000 a $3^{\circ}\left(19^{\circ}\right.$ a $\left.0^{\circ}\right)$, de donde resultaría que la temperatura variaría $1^{\circ}$ por cada 190 metros de altitud; más exactamente por cada 160 a $1 \tilde{50}$ metros en verano, o 145 a 120 en invierno, ya que la línea de nieve perpetua oscila 400 metros en torno de su nivel medio; por desgracia ese cálculo es puramente ideal: aquí a 800 metros de altitud hay tal temperatura y allá, a esa misma altura, aparece otra que difiere de aquélla hasta en 5 y más grados.

Como se comprende, el calor de las partes bajas y el frío de las alturas, haciendo papel de doble émbolo, incesantemente producen en las cordilleras preciso movimiento en el aire, por lo cual la atmósfera, como el mar, no sólo tiene sus corrientes, sino también su flujo y reflujo, $\mathrm{y}$ así como del tró. pico parten las aguas que calentarán las costas del norte, también de la llanura cálida arrancan los tibios vientos que harán lo mismo con las heladas cimas. Tenemos, pues, que de arriba y de abajo surge opuesto movimiento, en forma de vientos, los cuales al encontrarse, por más que quieran ambos a dos dejarse libre el paso, no lo consiguen a causa del relieve, chocan entre sí $y$, en cierto modo, se equilibran en una zona dada, neutra, por así decir, que se prolonga a lo largo de las serranías, marcando en ellas una especie de ecuador climático andino, especial, exclusivo al relieve tropical colombiano, la zona de la eterna primavera entre el eterno estío y el otoño secular, éste en ocasiones muy trastornado por el invierno $\sin$ fin, que, en vez de seguirlo en el tiempo, se trepa a las últimas cimas para dominarlo permanentemente con más facilidad.

Del examen de muchos centenares de temperaturas que corren en los libros, por más que no todas hayan sido tomadas con igual cuidado, pueden deducirse algunos conceptos de carácter general, que hacen plena luz en el asunto, si sólo se las mira como elementos de estudio para fijar las grandes leyes que rigen el clima del país. De dicho examen resulta en primer lugar que esa zona, andina por excelencia, se halla comprendida entre 1.300 y 2.400 metros, en los cuales se mezclan y entrecruzan seis grados (del $23^{\circ}$ al $18^{\circ}$ ), que forman una especie de núcleo con doble orla arriba y abajo; el núcleo lo señalan los grados 22 a 20 , cada uno de los cuales abarca unos 8 hectómetros, y los que 
se escalonan con diferencia de unos 100 metros; la orla superior la marcan los grados 19 y 18 , y la inferior los grados 23 y 24 , subiendo aquélla hasta los 2.400 , en tanto que la otra baja hasta menos de los 1.000 y enlaza por lo mismo sólidamente la zona andina templada a la inferior o cálida. Consecuencia de lo dicho es que la curva de nivel de 1.700 metros, es decir, la del límite su. perior del cultiơo del plátano hartón, corta cum. bres, faldas $y$ valles donde la temperatura es de $22^{\circ}$ a $19^{\circ}, \operatorname{los}$ dos últimos cerca de su principio $y$ los otros dos no lejos de su fin, pasando relativamente próxima al término del grado $23 \mathrm{y}$ al comienzo del 18 , de lo cual resulta ser $20^{\circ} 5$ la tem. peratura media de esta zona, que es por excelencia la del café, el alyodón y el guinco. Es así de ob. servar que los grados de esta zona, como que abarcan menos y menos amplitud de abajo hacia arriba, esto es, indican cierto predominio del frío sobre el calor destle los 1.000 metros de altitud, a cuya cota desaparece igualmente la verdadera vegetación tropical.

Abajo de esa zona, o sea descendiendo hasta el nivel del mar, se escalonan los grados 24 a $2 \bar{t}$, que abarcan tolos poco más de medio kilómetro y mar. can la verdadera tierra caliente, puesto que los siguientes de la serie ( 28 a $31^{\circ}$ ), son los tórridos por excelencia, como que el grado 31 nunca apare. ce a más de 200 metros de altitud, ni el 28 pasa los こ̃00, o sea el límite entre la llanura y las montañas propiamente dichas. Por lo demás, las brisas de las montañas $\mathrm{y}$ del mar explican las aparentes anomalías del clima de esta zona, que es la del cacao, el plátuno y el tabaco. Cuanto a las temperaturas medias de 32 a $36^{\circ}$, son locales y determinan los infiernos colombianos, siendo de advertir que ni aun en las faldas que enmarcan esos hornos sufren desvío las reglas generales apunta das. En fin, las temperaturas de hasta 40 y $42^{\circ}$ no son sino accidentales, de ciertos lugares o comarcas reducidas, en determinados días y condiciones atmosféricas y no se presentan a más de 500 metros de altitud.

Al contrario, volviendo la mente hacia las alturas superiores, tendremos que los grados 17 a 11 , por grupos, abarcan menos y menos amplitud, y en su conjunto señalan la tierra fría, es decir, la zona del pino, del roble, de la quina, de las papas, de la ccbada y de las habas. Los cuatro grados siguientes encierran también algro de anómalo, pues suben y bajan de un modo notable en los Andes y marcan otra zona variable o de transición, en la cual aún más acentuadamente prima el frío y abarca el páramo habitable. En fin, los primeros grados de la escala $\left(6^{\circ}\right.$ a $\left.1^{\circ}\right)$ se reparten los últimos 1.000 (hasta 4.000 ), guardan los postreros representantes de la regetación arborescente y cubren el páramo bravo, donde en verano suele subir la temperatura hasta $10^{\circ} \mathrm{y}$ bajar en invierno o en días de borrasca o tormenta hasta $0^{\circ}$, por lo cual aún se encuentra en él uno que otro lugar habitado, en los valles menos inclementes, puesto que hasta los 4.000 se cosecha la papa en los Andes, $y$ se mantienen ovejas, bien que no sin dificultades $y$ peligros.

Si tomamos los medios concretos de lo expuesto, puede lecirse que el grado 20 es el que abarca mayor amplitud altimétrica; síguenle los inferiores y superiores hacia arriba $\mathrm{y}$ hacia abajo, que reducen lit suya, pero con mayor dominio éstos y entremezclán. dose los de los extremos de la escala en reducida porción altimétrica: de alí la incomparable diferencia superficial entre las tierras cálidas y los páramos. Quizás forma una excepción el grado 1t, debido a lo extenso de las altiplanicies de la cordille. ra oriental.

De lo dicho resulta que la división altimétrica es la más importante para el país, $y$ debe basarse tanto en la temperatura como en las producciones naturales, de donde las tan conocidas tierras $c a$ licntes, tcmpladas, frias y paramosas del pueblo, bien que tal división esté lejos de ser correcta. Admitiendo el calificativo de templadas para las de cierta zona andina, la caliente comprende dos porciones esencialmente diversas, que llamaremos ecua. torial o tórrida, y tropical o cálida, para marcar climas de 33 a $29^{\circ}$ y de 27 a $24^{\circ}$. El término ticrras frías es correcto, en verdad, pero la voz páramo está en el mismo caso que el penúltimo y en aten. ción a que los arbustos suben hasta cerca de los 4.000 metros y luego ya cae nieve, subdividiremos la zona en frígida o páramo propiamente dicho o puna, hasta donde concluyen los verdaderos árboles, y polar o páramo bravo el resto.

Resumiendo, tendremos que las costas, las llanuras, el fondo de los grandes valles, el último trozo de las faldas de las serranías y los pequeños relieves sueltos, son tórridos y calientes; las cimas de los relieves medios, las faldas de las cordilleras y los valles medios, son templados; las altiplanicies, los altos valles, las altas faldas, son fríos o para. mosos y polares las crestas y cimas culminantes. En general, puede decirse que el país distribuye su territorio así : 1.000.000 de kilómetros cuadrados de tierra tórrida; 145.000 de tierra caliente; 135.000 de tierra templada; 100.000 de tierra fría y 45.000 de páramos, en los que la nieve ocupa 100, a lo sumo, permanente o accidentalmente; sólo para el Toli. ma se ha hecho cálculo riguroso, que dio 334 hec. táreas y en la Nevada de Chita, muy aproximada. mente, una legua cuadrada; el resto lo hemos deducido por comparación y cálculo de la superficie de los segmentos nevados. En fin, el país puede considerarse como una pirámide puesta sobre base muy extensa, en la que sin contraste súbito la porción occidental o transandina es menos tórrida que la oriental o cisandina, y la transmagdalenia más cá. lida que la cismagdalenia, entre la montaña; lo contrario sucede en la llanura atlántica. No hay, pues, un núcleo de donde como centro irradien los 
climas y el país carece, por lo tanto, de equilibrio en cuanto a clima, a la vez que el cruce de isotermas, isóteras e isoquímenas, modifica las zonas de vegetación, casi imposibles de determinar de un modo preciso, salvo para contadas plantas, que necesitan clima muy estable (1).

De estos diversos climas ninguno forma zona continua en el país: la cúlida puede considerarse como un océano en que se bañan varias islas, en especial una de continente doble, dentro del cual la tem. plada, a su turno considerada de la misma mane. ra, forma zona continua, mientras la fría aparece repartida en grandes $y$ pequeñas islas $y$ tratada a su turno del mismo modo, envuelve los páramos $y$ nevados como a islotes y arrecifes. Los nevados se tienden de SW. a NE.; la Sierra de Santa Mar. ta desciende por todos sus flancos hasta la zona cálida, pero los demás sólo lo hacen hasta las parameras recinas. Los páramos en Huaca (frontera S.) forman una herradura en que el brazo D se continúa sin interrupción por zona igual (Quin. dío) hasta Sonsón, con ganglios y algunas nerva duras, pues en seguida apenas asoma dos veces: mientras el otro se suspende de repente, luego (Chocó) levanta algunas como islitas y sólo muy al $\mathbf{N}$. crea tres grupos de mayor extensión; también un momento aparecen en la frontera de Costa Rica. La sierra de Chita es otro centro del que al SW. siguen páramos contiguos hasta Gachaneque, con varias nervaduras laterales, sobre todo en Toquilla, como también al N., hacia el Almorzadero; de éste vuelven a Santurbán para girar al $\mathrm{N}$. por largo trecho, aunque en discontinua faja, con bastantes nervaduras. De Gachaneque al NE. sale faja sos. tenida de alguna longitud y hacia el s. otra bifur. cada para marcar óvalo que concluye en un gran ganglio u ovalo que tiene algunas nervaduras que al E. forman martillo. De Gachaneque al NW. también va otro ramal discontinuo que forma ganglios y a su W. tiene otro núcleo aislado. En fin, junto a la Sierra Nevada hay otro islote en la Sierra Negra. La tierra caliente es continua en las lla-

(1) "Por esto los climas colombianos dependen más de las condiciones del relieve, de la exposición del suclo y de la direccion de los vientos que de la latitud de los lugares; las paralelas que se trazan sobre la redondez diel globo tienen poca importancia en un pais integramente situado entre los trópicos y que dos veeeg cada año presenta todas las partes de su superficie a los rayos verticales del sol. Cuanto a la altitul, razón principal del exealonamiento de los diversos ellmas en las faldas de las montañas $y$ en las terrazas superiores, sus efectos resul. tan modifiendos de muy vario modo por todos los fenamenos de la vida planetaria. De los calores tórridos de la llanura baja a los fríos polares de la eima nevada, sucédense todos los climas, pero no en proporeión directa de la rarefacción atmosferiea: las curvas de nivel $y$ las de los grados isotermicos en ningún punto van en línens paralelas: al contrario. en todas partes se entre. mezelan en inextrieable red. Asi, la division usual de las comar. cas montañosas en tierras calientes, templadas y frías, que para mayor precision se pueden dividir en tierras torridas, ealientes. templatas. frías y polares, no puete apliearse siguiendo medilas uniformes: los límites varían de una nontaña a otra, de nno de sus flaneos al opuesto. Fin su conjunto la zona templada, comprentida entre los grados 24 y 15 de la escala termometrica. abraza. preseintiento de los llanos, la parte más considerable de In superfieic colombiana: es ln zona donde los vientos frios que hajan de las alturas $y$ los cálílos que suben de la llanura se mantienen en equillbrio estable". - E. Reclus. nuras orientales, pero al S. queda aislada de las occidentales de su género; lo mismo sucede hoy en Cúcuta y Ocaña. La llanura atlántica constituye otro núcleo notable; el bajo Sinú la une al Chocó y por el Magdalena penetra hasta suara y Timaná, a modo de inmenso grolfo que hace senos en el Sumapaz, el Bogotá, el Negro, el Minero, el Simitarra y, sobre todo, en el Sogamoso-I,ebrija, puesto que por allí se interna hasta (rüepsa, ('apitanejo, Valle, Floricla, Girón, Iấionegror también por el Cauca entra como filete que despicle un brazo por el Nechí y luego avanza hasta Quilichao, sin in. terrupeión, mas sin entradas notables. El Chocó se une al Darién, y al $\mathrm{S}$. penetrat entre los Ancles a formar un gran golfo por el I'atía, $\mathrm{y}$ al $\mathrm{N}$. otros menores por el Murrí y el Sucio; Panamá es inte. gramente cálido, salvo pequeña faja al W. La tierra templada se prensenta con caracteres muy nota. bles; es orla de la caliente y une sus partes, pues del valle del Magdalena, por el lomo de Miraflo. res, pasa al Caquetá; entrà a Cáçueza, Gachetá, Garagoa, Labateca; pasa por el Uribante al Zulia y por Preblonuevo al bajo Maglalena: sin tropie. \%o une las hoyas del Prado al Minero-Charalá: arropa a Guamacó, sube a Meclellín y pasa a Arma, así como del valle del Caucia al del I'atía, para lle. gar hasta Imues, $y$ en dicho valle ocupa con fre. cuencia el lomo chocoano. La ticra fría forma una mancha en Th́querres, luegro dos angostas bandas seguidas descle Pasto hasta Sonsón y otro núcleo en Santa Rosa; también aparece de Paramillo a Río de Oro y Caramanta y forma algunos botones de aquí a Túquerres. El gran dominio de la tierra fría está en Bogotá-Tunja, de donde salen algunos ramales que forman arcos en torno de los valles templados $y$ arrancan fajas importantes seguidas hasta Pamplona y Tona, y de aquí más reducidas hasta la Mesa Rica (Ocaña), también con algunos apéndices. Lo que antecerle es muy importante, pues demuestra que el verdadero porvenir del país no puede ser otro que la explotación de las riquezas tropicales y por lo mismo serán mero lujo los ferrocarriles a las regiones frías, que casi no producen artículos de exportación; en no lejano futuro por cada reinoso habrá a lo menos diez calentanos. Una de las fatalidades del país fue sin duda establecer la capital en tierra fría y excéntrica por añadidura, y otra, que no exista ciudad importante hacia las fuentes del Magdalena, indisputable centro geográfico de Colombia.

Conforme de todos es sabido, los vientos dominan tes entre los trópicos son los Alisios, que según teoria generalmente aceptada, aun cuando discutible, provienen de la desviación de las corrientes de los polos al ecuador, generadas por diferencia de temperaturas y presiones y desviadas de occidente a oriente, o mejor dicho, al NE. y al SE., por virtud del movimiento de la tierra. Es claro que en el fenómeno también tiene parte la marcha anual del sol de trópico a trópico, de acuerdo con la oblicuidad de la eclíptica, ya que esa marcha lleva $y$ 
trae el ecuador térmico, bien que dejando predo. minar el alorico en el hemisferio norte, de sterte que nunca baja a nuestras costas atlánticas isoquimena inferior a $\stackrel{20}{\circ}$. por lo enal potemos afir. mar en cierto sentido que Colombia se tiende entre dos ecuatores, puesto que uno térmico cruza casi permanentemente el refericlo litoral.

Empero, la disposición y altitud del relieve colombiano no deja soplar libremente los Alisios, que tienen que estrellarse sobre los Andes: no domi. nan de una manera regular sino en la costa caribe, de ordinario con gran violencia, pues su fuer\%al se acrecienta por los focos ardentísimos que rodean el mar de las Antillas, conocido engendrador de los huracunes de las Antillas. Por fortuna esos huracanes jamás asuelan a Colombia: apenas sucede que los vientos del E. $y$ del NE. llegan convertidos en tempestad y hacen estrellar el mar en las playas sin abrigo. Los violentos Nortes del golfo de México tampoco alcanzan nuestra costa sino muy decaídos. Con frecuencia, cuando el sol está al N. de la equinoccial (julio a noviembre), corren a lo largo de la costa los reudacules (vientos de "aval", o sea del W.), mas sin prevalecer en tierra sobre el alisio; mientras el vendaval aparece en las altas regiones atmosféricas, la corriente marí tima del W. que baña la costa, marcha con velo cidades de más de 7 kilómetros por hora.

Cuanto al alisio, que sopla con más fuerza en el día, aumenta su velocidal cuando se levanta el sol, y declina con dicho astro, de manera que casi des. aparece por la noche. En la Costa y los Llanos hasta lo reemplaza la brisa de tierra (en el Llano brisi del cerro), causada por el enfriamiento del suelo, lo cual hace especialmente gratas las primeras horas de la noche en todas las tierras cálidas, puesto que en todas se presenta entonces la brisa, bien que con varia intensidad (1). En las altiplanicies de la cordillera es al amanecer cuando cesa la quictud de la atmósfera y corre brisa tan fresca como penetrante, porque los alisios convergen de la llaumra hacia los páramos que se tienden de Chita a Sumapaz, por lo cual, según la estación, llegan del SE. o del NE. En los valles del Magdalena y del Cauca-Patía, el viento que transmonta las cordilleras es desviado hacia el N., en tanto que en el bajo Magdalena el rumbo de las corrientes alterna del N. al S. y del S. al N., con el del NE. y el del NW.

Los alisios del hemisferio norte corren con su máxima regularidad cuando el sol está al $\mathbf{S}$. del ecuador (noviembre, marzo), tirando entonces fran-

(1) "Las noches elaras $y$ bellas transenrren entonces deliciosas, sin dar la sensación de tlempo: el alisio no corre $y$ las brisas contrarias se mantienen en equilibrio sobre la selva. La luz di fusa hace los objetos visibles por graudes masas hasta el lejanu horizonte, pero la mirada se dirige invenciblemente lacia la bo. veda celeste. de un color negro transparente, salpieacla de luz

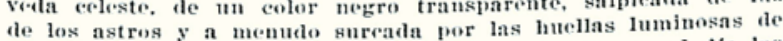
de los astros y a menudo sureada por las huellas luminosas de las estrellas crrantes, Si a la hora de mayor ealor en el dia los habitantes se entregan a la siesta. es decir, se refuginn en los sitios mis freseos $y$ oseuros de las viviendas, durante la fresen noche, al contrario, todos salen al aire libre para respirar con entera libertad, para gozar de todas las dulzuras de la vida $y$ de la sociedad". . - E. Reclus. camente del NE. y aun del N.; pero calman y dejan campo a vientos instables del S. y SE. cuando el sol se ha trasladado al $\mathrm{N}$. de dicha línea equinoccial (abril, octubre). Entonces es cómoda la navegación de bajada en los ríos orientales, porque el viento del W. ayuda a las barcas $y$ es, al contrario, penosisima la operación inversa. En la época del viento normal la corriente aérea $y$ la fluvial avanzan en dirección contraria, lo que facilita los viajes de las barcas: en los ríos de mínima pendiente, como el Arauca, sucede que una parte de las aguas remonta con el viento, mientras la otra sigue su curso normal. Si entonces hay cambio de tiempo, acaecen chubuscos temibles, que producen violento oleaje.

El alisio poco se deja sentir arriba de los raudales del Orinoco y los montes de la Guayana cie. ran el paso a los vientos del E. para las regiones intermedias entre esos raudales y los del Rione. gro. Alli hay sitios donde, como en algunos del interior, es fama que nuncia hace riento: la atmós. fera se mantiene perfectamente tranquila, el calor es insoportable $y$ los mosquitos llenan el espacio: tan densas son sus nubes. Alli los rayos de tem. pestad sin trueno son más comunes que en otras partes, en especial al aproximarse la época de las lluvias: "Diriase que el aire palpita en sacudidas luminosas". También en la entrecordillera, donde el calor es más intenso y la atmósfera se renueva menos, con frecuencia el aire es completamente inmóvil.

En Panamá los alisios del hemisferio N., por la disposición del terreno, soplan más bien del $\mathrm{N}$. que del NE., y en la época lluviosa (mayo-noviembre) ceden el campo a los vendavales o alisios del SE., transformados en una especie de monzón. En la costa N. NW. del Istmo, los Nortes suelen ya causar algún daño, lo mismo que los huracanes, que en más de una ocasión han producido considera. bles naufragios.

Cuanto a la zona del Pacílico (Chocó), como se perfila libremente entre los alisios de los dos hemisferios, aunque barrida regularmente en verano por vientos del N., por su posición, resulta sometida a los remolinos producidos por el choque de los los vientos mayores, de donde que allí domine una banda de brisas locas y de calmas, esencialmente molestas para los buques de vela. Las corrientes marítimas, ayudadas por mareas de hasta 12 metros, también son muy variables al $\mathrm{N}$. de la Buenaventura. Hacia la frontera ecuatoriana ya los vien. tos soplan del S. y del W., lo que no impide que los cordonazos de San Francisco se dejen sentir allí tau regularmente como en la América Central y causen iumdaciones represando las bocas de los ríos.

En las regiones ecuatoriales las estaciones están regulatas por las lluvias, que a su turno obedecen a la marcha del sol. Llueve cuando ese astro está cerca de la equinoccial, en tanto que el cielo se con. serva despejado cuando se aproxima a una u otra 
línea tropical. Por esta razón dos veces al año las nubes lluviosas pasan sobre el país, que en tesis general debería tener dos estaciones alternadas de lluvia y de sequedad: verano $e$ invierno. Esto sucede, en efecto, en los llanos, donde el invierno y el verano se reparten por mitad el año; pero se modifica en las cordilleras y en las selvas amazó. nicas; allá porque resultan dos períodos trimestrales lluviosos separados por otros dos secos, en tanto que acá llueve nueve meses, por su proximidad a . la equinoccial y por la disposición del suelo. Mas debe advertirse que esas estaciones no son tan regulares y precisas como las de la zona templada.

Por causa de la disposición del relieve de Colombia las lluvias más copiosas caen sobre los dos frentes (E. y W.) de los Andes y también sobre la Sierra de Santamarta. En todo caso, la cantidad media de lluvia que en el año recibe Colombia, supera en mucho a la que cae en las regiones templadas de Europa, si se exceptúa la Goajira; en la Sabana ya excede de un metro; pasa de dos en la Costa, rebasa los tres en la falda oriental de Sumapaz y el Caquetá y la Costa W. de Panamá, y alcanza los cuatro en la hoya del Atrato. Sólo en la Goajira no pasa de 0.50. En general, la capa media de lluvia anual puede estimarse igual a 2 metros para todo el país, y su volumen disminuye, como se ve, de la periferia al centro.

Esto sentado, Colombia, por lo que a lluvias hace, divídese netamente en tres zonas: la en que llueve siempre o poco menos, que es la mayor $y$ abarca las regiones llanas y selvosas del W. y mediodía; la en que llueve dos veces al año $\mathbf{y}$ comprende la montaña, pero en la que el fenómeno es más re. gular al $\mathrm{N}$. que al S.; y en fin, las llanuras herbáceas, en las que con mucha exactitud medio año

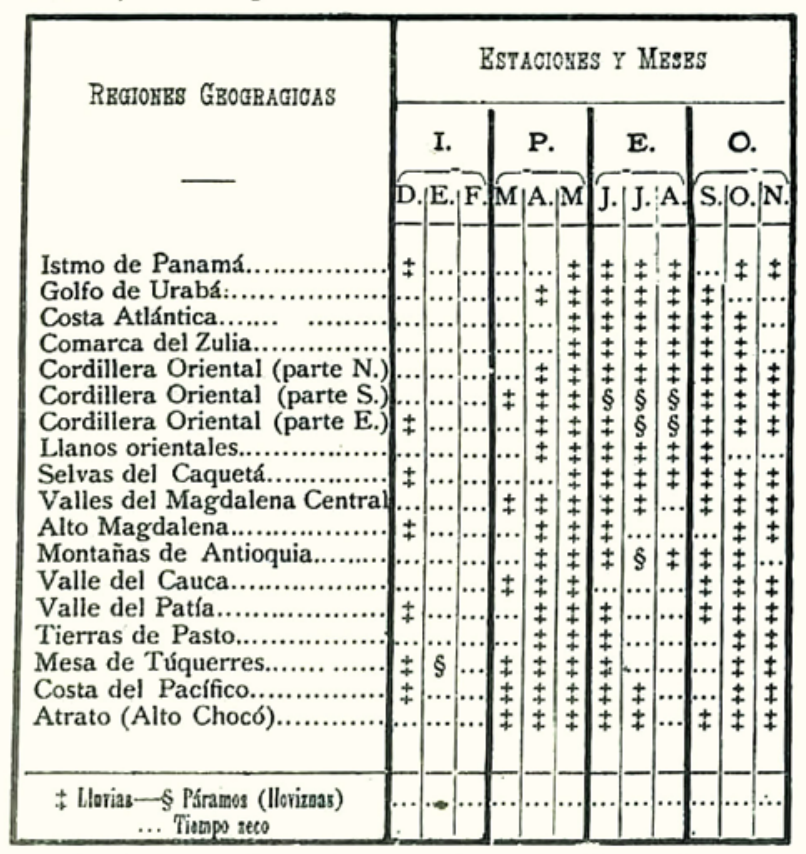

$\mathrm{I}=$ invierno $; \mathrm{P}=$ primavera $; \mathrm{E}=$ estío; $\mathrm{O}=$ oton̄o. Cuadro sintético del régimen anual de las lluvias en Colombia. llueve sin interrupción y medio año escampa, y que comprenden la región atlántica y el Llano. Como esas zonas están en íntimo contacto y los vientos pasan a veces con suma facilidad de una a otra, prodúcense alteraciones, tanto más cuanto una sim. ple colina, una faja de bosque, bastan para detener las nubes, de donde resulta que muchas veces dos porciones de suelo vecinas aparecen distintamente regadas y al contrario. En la costa, o sea en la llanura atlántica $y$ en el Llano, llueve de abril o mayo a octubre o noviembre, o sea del equinoccio de primavera al de otoño; en Panamá el fácil contacto entre los vientos de dos mares retrasa la estación lluviosa hasta un mes, pero en cambio lo prolonga luégo, por lo cual resulta mucho más larga que la de sequía. En las montañas las dos estaciones secas principian con los solsticios y las lluviosas con los equinoccios, o sea duran 90 días cada una, salvo en los valles bajos y selvosos, donde la lluvia se hace casi permanente, sobre todo si se avecinan al del Magdalena central; puede decirse que la estación aquí es mixta, pues dura nueve meses, porque al invierno de las costas se agrega el segundo de las cordilleras. Como se comprende, en tres meses no alcanza a secarse ese suelo y de ahí lo pantanoso y húmedo que es. La estación lluviosa en las cordilleras varía un poco, como dijimos, del N. al S., pues aun cuando sigue al sol en su carrera, al S. está entre zonas de perpetua lluvia, de donde resulta que los páramos al N. están más despejados en septiembre y al S. en febrero. Adviértase sí que con frecuencia en los páramos se in. vierten las estaciones, pues durante la sequía de las faldas, las nubes que origina el trópico son relegadas a las más altas cumbres, donde son entonces frecuentes las tormentas, granizadas y nevadas, causa de crecientes de los ríos, singulares a primera vista; baja entonces el nivel de la nieve $y$ es más peligroso cruzar los páramos, tanto por el frío como por los huracanes. AI contrario, durante la época lluviosa de las faldas, las mayores cumbres están secas, no sufren temporales y su frío es menos intenso. En los páramos no es tanto el frío cuanto el influjo de un viento fuerte $y$ destemplado $y$ de un aire nebuloso, lo que los hace inhabitables; a decir verdad, en estas regiones llueve todo el año, puesto que cuando allí hace verano, no faltan lloviznas causadas por los pocos vapores que hasta ellos alcanzan, principalmente en enero $y$ febrero, y al cruzarlos es siempre peligroso hacer ruido porque este desequilibra la atmósfera, el aire frí vence entonces al cálido $\mathrm{y}$ se precipita hacia abajo y origina la tormenta. En general, pues, los mayores temporales de los páramos ocurren en junio y agosto; truena más en febrero, marzo y octubre; las nubes tempestuosas corren de E. a W., o de W a E., a partir del Magdalena; los más recios chubascos caen después de las 2 p. m., y, aunque fuertes, duran poco, dejando luego sereno el cielo. Por último, las cimas que sobresalen mucho sobre el suelo aledaño, resultan siempre más tormentosas, 
tanto más cuanto más altas y más rodeadas por valles cálidos están, a la vez que desvían los vien. tos, se arrojan de unas a otras las nubes $y$ causan las más singulares perturbaciones. En el Chocó y en el Darién llueve el año entero, sobre todo en el bajo, a donde parece se concentran la humedad del Perú : pues al N. hay cambios por causa de los alisios que entran por el golfo de Urabá. En Panamá la costa norte expuesta al alisio recibe por lo menos dos veces más agua que la del sur, que se vuelve hacia el monzón. En el Caquetá sucede otro tanto, bien que en unas zonas llueve más que en otras, o bien el verano $y$ el invierno se diferencian un poco más por la cantidad de lluvia caída en esas épocas; también aquí como en el Magdalena central hay, pues, una combinación de las estacio. nes, lo cual, por otra parte, causi ciertas pertur. baciones en el alto Magdalena. En general, las comarcas tórridas, húmedas, selvosas, del Chocó hasta el Caquetá, están situadas en lo que se llama la zona de las calmas, es decir, desproristas de vientos, por lo cual la grande evaporación de un suelo tan húmedo no es alejada, sino que se acumula en el mismo lugar en forma de negras nubes que se deshacen en lluvia cuando el sol pasa el zenit, la que terminada, deja campo a la evaporación que, al ponerse aquel astro, torna a caer en nuevos aguaceros, casi siempre acompañados por fuertes y uumerosas descargas eléctricas $y$ sostenidos muy a menuclo hasta el amanecer, repitiéndose sin cesar el mismo ciclo, que, como es natural, mantiene atmósfera húmeda en demasía; cuando soplan algunos vientos, llegan los días sin lluvia, entre noviembre y marzo, pocos en el Chocó, más numerosos en el Caquetá. En los valles selvosos y encerrados pasa algo semejante, por cuanto los vapores no alcanzan a salir del marco de la cuenca, caen fundidos en la misma $\mathbf{y}$ sostienen excesira hume. dad, cansa de mayores lluvias. Al contrario, en los Llanos, por cuanto son regulares los vientos, las estaciones son siempre marcadísimas: llueve segui. do de abril a octubre, o sea con un mes de diferencia sobre la costa panameña, $y$ el verano real o de absoluta sequedad no aparece sino en diciembre. enero y marzo, pues en los otros meses no falta algún aguacero, así como en el invierno alguna interrupción o verano. En la costa atlántica la aislada Sierra Nevada de Santamarta, como es natural, causa o produce condiciones singulares en el clima que la envuelve.

Por lo demás, como en todas partes, el invierno tiene variaciones, pues ora los aguaceros son torrenciales, pero sólo de algunas horas, ora menores $y$ constantes hasta por treinta $\mathbf{y}$ aun más horas, ya a modo de chaparrones con truenos y granizo; un día llueve por la mañana, otro por la tarde, y aún hay días en que no cae una gota de agua. Al contrario, en el verano no es raro que caigan algunos aguaceros; aunque menos fuertes. En el máximum del invierno realmente tropical o de seis meses, hay una singular interrupción que se llama verano de San Juan y dura algunos días hacia fines de junio, el cual interrumpe en las cordilleras las garúas, tan destempladas $y$ molestas entonces; en diciembre. en los últimos días, hay en éstas otro verano llamado de San Martín, $\mathbf{y}$ por último, hacia los primeros días de febrero caen algunos aguaceros que se llaman de la Candelaria. La causa de estas anomalías la indicaremos en su lugar.

En fin, las nieves perpetuas, contra lo que han escrito muchos, of recen en Colombia una horizontal casi perfecta, ya que en sus extremos está a 4.560 metros, término medio, tanto en Chiles $y$ Cumbal como en Santa Marta, muy poco menos en Chita y muy poco más en los nevados del Quindío: casi en todos hay heleras, las que por término medio bajan hasta 4.350, quedando más altas en Santa Marta y más bajas en el Huila, donde, contando desde el pie de ellas, la nieve mide 900 metros, cuando en Chiles sólo muestra 367, en Cum. bal 339, en Puracé 300, en los demás Coconucos 240, en Santa Isabel 400, en el Ruiz 740, en Herveo 870, en el Tolima 1.240, en Chita $900 \mathrm{y}$ en Santa Marta 800. En invierno la nieve suele bajar hasta $3.900 \mathrm{y}$ en verano retirarse hasta $\operatorname{los} 4.750$, lo cual significa que la nieve oscila unos 650 metros, bien que esto es enteramente accidental; de 4.000 a 4.200 la nieve sólo dura días $y$ de 4.200 a 4.400 algunas semanas, pero hasta los 3.800 metros los temporales suelen ser de nieve más que de agua. De lo dicho resulta que en invierno nievan en Colombia varias cimas, así como también que se ha exagerado mucho la altura de otras. Los nevados decrecen sin cesar, a juzgar por los datos recogidos $\mathrm{y}$ con esto ayudan a modificar el clima; por ejemplo, antes que el $\mathrm{Pu}$ racé perdiese 200 metros de nieve por hundimientos de su copa, los vientos helados dominaban en la llanura de Cajibío, en la que se cultivaban frutos de clima frío $y$ no existían serpientes de tierra caliente: pero después de ese hundimiento el clima subió varios grados, hoy allí no se da el laurel de cera $\mathbf{v}$ pululan aquellas serpientes. También a Cartago se daba temperatura de $24^{\circ} 5$ al principio del siglo pasado, cuando era opinión general que en el Quindío había más topes nevados y éstos, más en. lazados entre sí, formaban un solo todo: hor Car. tago tiene $28^{\circ}$ y esos nevados, menores en número. están perfectamente separados entre sí, salvo los días de tormenta, en que la pampa intermedia se cubre con 10 a 20 centímetros de nieve: iserá esto por derrumbes de las nieves o por disminución de nivel? Lo ignoramos. Bueno es hacer notar que en muchos lugares la temperatura se ha disminuído a sabiendas en las publicaciones, creyendo que con esto se alucina a los extranjeros.

Otro elemento necesario para la perfecta inteligencia de nuestra climatología es la amplitud de la variación de la temperatura al aire libre, pues en unos lugares es casi insensible $\mathbf{y}$ en otros presenta intensas modificaciones. En las altiplanicies. 
por ejemplo, no es raro que baje a $0^{\circ}$ al amanecer $\mathrm{y}$ alcance a 22 a las dos de la tarde, es decir, que presente una variación de $22^{\circ}$; en Panamá cuando pasa de $30^{\circ}$ al medio día, a 22 a la entrada de la noche, todos se quejan del repentino cambio del tiempo; en Popayán es raro que la oscilación exceda de $3^{\circ}$ en el día. A este respecto tenemos, pues, climas constantes, climas variables y climas extremos, tanto por lo que hace al día, como considerado el año entero; en este último caso suelen encontrarse oscilaciones hasta de $30^{\circ}$ a la sombra $y$ de $50^{\circ}$ al rayo del sol.

Por otra parte, la enorme diferencia de temperatura entre las cumbres $\mathrm{y}$ los valles ardientes, a veces apenas separados por escarpadísimo muro, hace que el aire frío de aquéllas y el cálido de éstos baje $\mathbf{y}$ suba por las estrechas cañadas con violencia tal, que cerca de la cresta adquiere la furia de huracán que imposibilita el paso en ciertas horas y quema la vegetación; en crestas más bajas entre dos valles ardientes o en los corredores montañosos, ese huracán destroza los edificios y desarraiga los mayores árboles. En la parte baja poco se siente el viento, pero el aire se enfría mucho y reduce de noche las temperaturas, a veces hasta en $15^{\circ}$, con mucha frecuencia en $10^{\circ}$, lo cual, unido a las aguas, que también suelen llegar frías o poco menos, produce climas malsanos en sumo grado. Ese cambio tan notable de temperatura origina abundantes rocíos que producen espesa neblina que ocupa el fondo de las depresiones mientras los topes surgen limpios, hañados por un pálido sol. A medida que éste se levanta sobre el horizonte. también lo hacen las nieblas, lentamente, hasta llegar antes de medio día a la zona templada, dejando así despejado el fondo; pero al llegar el astro al zenit, obra más sobre ellas $y$, o las levanta en rápidos torbellinos, o las reúne para formar las nubes de tormenta : en verano, cuando el sol las levanta, producen en la falda tenue llovizna o lluvia corta, que se llama alzar la niebla o pasar la nube, pero por la tarde retornan a la falda, o bajan a beber agun, como aquí se dice. Esas nieblas en los topes paramosos, cuando el sol los calienta hasta los $23^{\circ}$ al aire libre, originan llovizna q̣ue humedece las cumbres, produce ricas mantas de gramíneas y fuente. cillas principio de los ríos y son causa de su clima tan destemplado $y$ variable. De lo dicho resulta que la hora mejor para cruzar los páramos es la de la mañana, cuando están despejados y el equilibrio del aire es completo; después, ese equilibrio se hace instable, $y$ por las nubes que los envuelve, aquí se les llama rucios. Como los corredores montañosos se abren de $\mathrm{N}$. a $\mathrm{S}$., allá hay más tierra caliente, acá forman los páramos masa más compacta y el alisio del NE. encuentra amplias puertas, por lo cual el viento que domina en los valles montañosos no fríos es de N. a S., o bien de E. a W., o a la inversa, según sea la falda con respecto a la vaguada ardiente, de ordinario en calma al medio día.
Por lo hasta aquí dicho, puede verse que el clima en las diversas partes del país tiene cierta igualdad anua, bastante extrema en las partes altas $y$ bajas, primaveral en la media; $y$ a un tiempo $y$ por siem. pre muestra superpuestas las cuatro estaciones que el año hace rodar en otras latitụdes. Resumiendo lo que antecede, tendremos: las elevadas serranías cubiertas, en escala descendente, hasta los 3.000, por nieves, pajonales, arbustos sueltos $\mathrm{y}$ algín bosque, constituyen el páramo, en general escaso en vegetación y combatido por vientos secos cuya influencia llega hasta la llanura. A su pie, la tierra fría, hasta los 2.400 metros, se compone en general de grandes montes que guardan algunas planiçies, ralles selvosos, aguas vivas, terrenos fértiles, cielo a menudo claro y melancólico, todo combatido por vientos tan impetuosos como fríos. Más abajo. hasta los 1.000 metros, queda la región templada, fértil, rica en aguas y selvas, a veces fría a la sombra, con notables variaciones en la temperatura del día $y$ la noche $y$ cielo con frecuencia nebuloso, sobre todo al ponerse el sol, cuando las nubes se aproximan al suelo; la temperatura varía tanto menos con la altitud cuanto más insensiblemente cambia ésta $y$ menos bosques hay. En fin, la región caliente en que la vegetación vigorosa cubre con manto de eterna juventud un clima ardiente, mientras el cielo muestra lejanos, frecuentes y silenciosos relámpagos, permanece medio año cubierta por un velo $\mathrm{y}$ entonces, aun cuandlo no llueve, abundante rocío humedece las plantas: faltan si las praderas de fresca y tierna yerba salpicada de flores.

También nuestros climas se caracterizan por los movimientos del barómetro, pequeños pero siempre regulares, horarios e imperturbables, cualquiera que sea la altitud del lugar, no menos que por los más varios del termómetro en la montaña: por vientos que aunque secos, en las alturas mantienen la frescura y el verdor de las plantas, merced a precipitaciones de la humedad que provocan. $x$ en la parte baja, saturados de lumedad a pesar de su trans. parencia, sostienen la vegetación, de otro modo imposible en regiones donde falta largo tiempo no sólo la lluvia sino hasta el rocío, bien que en éstas la sequedad aumenta día por día. como en la Goajira. hoy por esto casi inhabitable: de ordinario las nubes más bajas están a 1.200 metros y causan las densas nieblas aue envuelven esa zona parte del año $y$ las más altas y espesas a 3.300 bien que vapores leves llamados earneros rebasan la altura de los nevados, en los que el higrómetro marca $25^{\circ}$ cuando llega a $\mathbf{1 0 0}$ en las selvas hrimedas del Chocó-Caquetá, siendo aquellos carneros los que dan las partículas que reflejan la luz solar y orlan a media noche. con pálido resplandor. el tope de las cordilleras, como brilla de lejos la atmósfera de una cindad iluminada por la electricidad. Este flúirlo abunda en el remate de la zona templada, como es natural, por la lucha del calor $y$ el frío $\mathrm{y}$ el roce de los fuertes y encontrados vientos; allí sus explosiones son más violentas y frecuentes, so. 
bre todo al pie de las cimas nevadas que surgen casi rodeadas por valles cálidos; en la zona fría son menos frecuentes $y$ periódicas, pero se forma mucho granizo, principalmente en los páramos, por cuanto allí hay casi siempre electricidad negativa, la que no sé halla sino corto tiempo abajo de los 1.000. En la regrión polar o de los nevados, el granizo cae $\sin$ tronadas, con nieve, aun en mitad de la noche, pero los rayos son muy raros. En fin, en los grandes valles, principalmente en los murados por altas crestas, las tempestades son constantes y frecuentemente ocurren entre el anochecer $y$ la media noche, sobre todo en ésta, $y$ las tormentas, de ordinario periódicas, estallan dos horas después de culminar el sol, cuando el flúido se acumula en las primeras nubes, es mayor el calor y casi mí. nima la marea barométrica, por lo cual nuestro gran río bien merece el dictalo de padre de las tem. pestades. Por último, todos los demás fenómenos meteorológicos tienen aquí cualidades propias, como sucede con el azul del cielo, más intenso en las grandes alturas, a la inversa de la refracción horizontal y de la lu\%, que en ciertas zonas bajas adquiere brillo y transparencia imponderable, que si auxilia a la vegetación por darle mayor desarrollo, fatiga el ojo y los nervios y hace más simpáticos los más velados paisajes de las altiplanicies frías. a pesar de su carácter melancólico (1).

Conviene ahora tratar de la nosografía en gene. ral, antes de precisar algunos datos elimatéricos sobre cada una de las porciones en que hemos di. vidido el país. También en este punto la altitud, así como agrupa los productos de los diversos cli. mas, agrupa las enfermedades de todas las zonas, con el item de haber algunas que se hallan a todas las alturas $y$ otras que son en cierto modo características de nuestro suelo, ora por la ardiente temperatura de la región baja, ora por las repentinas transiciones del aire en las altas cumbres. $A$ este respecto, el país en su patología of rece no menos vicisitudes que la historia de sus hijos, pero sin mejorar en definitiva; a las enfermedades nativas del terreno se juntan hoy las exóticas, tanto más aprisa aclimatadas $\mathbf{y}$ aun complicadas con otras, cuanto menor o nulo fue el esfuerzo hecho para im. pedir esa invasión o siquiera retardarla: precisa ha sido la bondad general del clima para que la población haya podido aumentarse, más o menos bien o mal, en todas sus regiones.

En la tierra caliente, a menos de 1.000 , sea costa, valle o llanura, cuando el suelo no es barrido por vientos continuos, a causa de la humedad impera sin rival el paludismo (o anemia o malaria), que no respeta raza ni edad, es el grande obstáculo

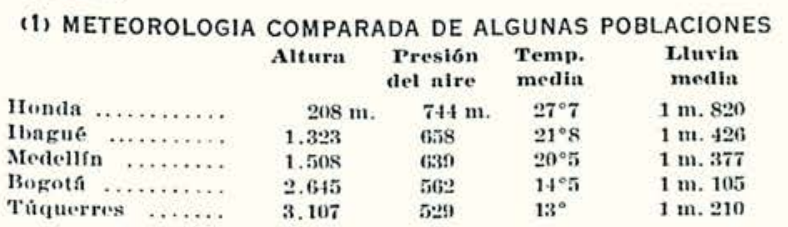

que se opone a la inmigración y mejora de esas fértiles regiones, $y$ rige no sólo la vida del individuo sino también el modo de ser de la localidad que habita. A semejante azote se une hoy el de enfer. medades venidas del viejo mundo $y$ el de las fiebres amarilla $\boldsymbol{y}$ biliosa remitente, endémica ésta, esporádica aquélla, lo mismo que otras de tal clima. Las fiebres intermitentes son comunes al entrar el verano, $y$ las éticas hacen estragos, no sólo a causa de lo ardiente del clima, que agota al individuo, sino también por la vida fácil y la sífilis que esto ocasiona o generaliza más y más; en algunos lugares causa horror el punto a que esto ha llegado. En los parajes cálidos batidos por el aire de los nevados son muy frecuentes la tisis y demás afecciones graves del pulmón. Debemos nombrar tam. bién la hiperhemia intertropical, que tanto perjudica a los ojos; las diarreas, la hepatitis, hipertrofia del hígado y el bazo; los exantemas febriles, las epirlemias de erisipela, la hematuria chylosa; las mordeduras de animales ponzoñosos, la tenia; la linfangitis perniciosa, probablemente palustre, que ora se parece al reumatismo articular, ora a la erisipela ambulante $\mathrm{y}$ termina por supuración; el beriberi, contagioso, que a veces alcanza a ser epidemia: las úlceras rebeldes y escrofulosas; las fie bres eruptivas, la caquexia palustre, el cólera, por fortuna muy raro, y la común y peligrosísima in solación. En general, puede decirse que las enfermedades de esta zona son producto o consecuencia de una intoxicación. De ordinario parece que existe cierta atracción entre el paludismo $y$ la disentería que abunda sí mís en las regiones altas, como si fuera el paludismo de la región fría. La raza negra de la región cálida sufre especialmente la forunculosis, la eczema, la psoriasis, que es la lepra de ella, la cloasma, el beriberi, la elefantíasis de los miembros inferiores $y$ del escrotum, es. pecialmente el ä̈hhum, y si bien resiste mejor el paludismo, la sífilis la devora con increíble fuerza. Hasta enfermedades que al parecer sólo deben hallarse en la región fría. se presentan aquí en la cálicla, como la gripa, la bronquitis, la tuberculosis. La viruela, esporádica, hállasela en todas partes, pero si causa más estragos en esta zona, de la cual es exclusivo el carate, contagiosa cuanto repugnante enfermedad que presenta varios tipos, ataca en especial a la gente mal vestida y mal alimentada y sujeta a rudas labores, cuya piel convierte en escamas de camaleón; de preferencia se desarrolla en los suelos secos, silíceos y feldespáticos, y en el Valle de Upar lo atribuyen a picaduras de un mos. quito especial. El tétanos y el cúncer, relativamente raros en tierra fría, son frecuentes en tierra caliente, por lo cual son allí muy peligrosas las más leves heridas, sobre todo en el Valle del Canca, donde es tan común el segundo, que la gente lo mira como contagioso. En el Llano figura además una ulceración que empieza como botones de Biskra, pequeñas induraciones cutáneas $y$ que repite despuess de la curación. Tanto de la tierra caliente 
como de la fría son el coto (bocio), sobre todo de la templada, terrible enfermedad que embrutece la raza humana y que proviene del uso de malas aguas. En fin, la más espantosa de las enfermedades, la elefantíasis de los griegos, extiende su lúgubre manto sobre todo el país, por falta de cuidado y de lazaretos; le hemos observado marcada antagonismo con el carate, se desarrolla principalmente en los suelos calcáreos y por error el pueblo cree la causa el más ligero enfriamiento repentino del cuerpo, en especial si se deriva de bebidas agridulces frescas. Lo dicho pudiera hacer formar juicio desfavorable de las tierras cálidas, que tanto se han desacreditado contra toda verdad; pero no: a la sincera enunciación de sus inconvenientes debe seguir lo que son en la práctica: tiempo hace que allí no hay grandes epidemias de ninguna especie; la mayor parte de los colombianos residen en ellas, aumentándose su número sin cesar, salvo muy contados puntos en los que la población está casi estacionaria y esto a pesar de la ninguna higiene del pueblo, de su falta de recursos y auxilios médicos, de los desmontes y de la explotación de selvas y minas. De lo dicho se deduce que es la gente pobre la que sufre más y la que por sus tareas está más expuesta a las picaduras de insectos $y$ alimañas, lo cual explica también su costumbre de no recorrer el campo sino en las horas de luz.

Por causas enteramente geológicas, algunos sitios como Cartagena, la hoya del Rionegro, etc., presentan enfermedades especiales al par que singulares. La tala del bosque, la desecación de los pantanos, el cultivo del terreno, mejorará día por día esta zona, como lo demuestra la experiencia, ya que hasta en sitios mal reputados se encuentran personas octogenarias y aun centenarias. Como en la época del descubrimiento, nuestro suelo, por razones obvias, era más sano y sostenía una raza de seguro aclimatada, los mestizos a que ella dio origen, son, junto con los derivados de la raza negra, la esperanza de la patria para vencer los inconvenientes de esta zona, la que ese día por sus aluviones, únicos en feracidad, sustentará un pueblo de los más opulentos del globo. Resumiendo, tendremos que en verdad no son malsanos sino los sitios privados de ventilación, sobre todo si son valles hondos, a causa de la intensidad de miasmas que produce la tem. peratura cuando llega a $24^{\circ}$, por reflexión del calórico radiante. También en los valles sujetos a periódica inundación del bosque, el paludismo alcan. za proporciones colosales; en cambio, en las costas $y$ playones sin manglares ni mezcla estancada de aguas dulces y saladas $\mathrm{y}$ batidos por la brisa, el clima es sano, absolutamente sano. Por desgracia, el más eficaz de los medios para combatir la intoxicación palúdica, el uso de los sanatorium, es aquí del todo desconocido o desusado por el pue. blo, si no es en pequeña escala, o sea en los suelos en que la inundación periódica le obliga a ser trashumante o poco menos.
En la región fría la nosografía cambia de aspecto: el paludismo y la fiebre amarilla, o no existen o no revisten gravedad mayor; la viruela fue más perniciosa, pero retroceden sus estragos ante la vacunación cada día más general, pero aún por des. gracia, no obligatoria. La gran epitlemia de esta zona es el tifus (que en la cálida pasa inadvertido entre hermanos más crecidos), y la tifoidea es, puede decirse, endémica. Hállanse el reumatismo agudo y sobreagudo; las sífilis, tan desarrollada en las ciudades como en la zonil cálida, por falta de disposiciones legales; las afecciones agudas, simples y complicadas del pulmón (las más mortíferas en el ejército); la bronquitis y las demás conocidas de las vías respiratorias, sobre todo las crónicas, seguidas de complicaciones cardíacas; las afecciones del aparato digestivo (diarreas, disenterías, catarros, etc.) ; las del corazón $\mathrm{y}$, sobre todo, las del hígado, principalmente la supuración. Tam. bién abundan el raquitismo y la sordomudez, si el clima es muy húmedo; a veces la caída de los dientes; la verruga o pirexia, con erupción de extensión varia $\mathrm{y}$ distinta forma, contagiosa, de mal carácter; los epiteliomas del rostro, lentísimos en su crecimiento, pero que reaparecen después de cortados; las afecciones puerperales y la coqueluche, que hacen estragos en madres y niños; la rlematosis; la fiebre eruptiva y el mal de San Antón (lepra). En los páramos priman las oftalmías, las afecciones del pecho y el emparamamiento. En toda la zona fría abundan las afecciones nerviosas, principalmente las neural. gias; $y$, por último, señalaremos la más grave de todas, la tisis mesentérica, que junto con la clorosis, ambas muy comunes, producto esta de un aire pobre en oxígeno, causa verdaderos estragos. En resumen, la zona fría, si es sana $y$ a la inmigración ofrece magnífico lote, su aire pobre, por dilatación, alimenta una raza poco fuerte para el trabajo de donde que resulte mayor la longevidad media en la tierra caliente.

Ahora, concluídas las premisas, consideremos a la ligera las diversas regiones en que climatérica. mente puede dividirse el país: al NW. tenemos el Istmo, que sin el Darién, ofrece clima esencialmen. te marítimo; al W. el Chocó con el Darién; a la I. del Magdalena la Mesa Andina (central izquier. da), que comprende a Túquerres, Pasto, Almaguer, Popayán, Valle del Cauca, cañón del mismo y Mesas de Antioquia y Chocó; a la D. del mismo la IIcsa Granadina (central derecha), que comprende n Fusagasugá, Rionegro, Muzo, Cáqueza, Tenza, Bo. gotá, Tunja, Socorro, Chita, Soto, Ocaña, Pamplo na y Cúcuta; la región atlántica, al N., con el Sinú, María, Santamarta, Valle de Upar, Goajira y Maracaibo; el Caquetá al SE., y el Lluno al E. Como se comprende, esta división no es absolutamente precisa, ya que el clima a veces varía de una a otra sin transición repentina y que en ellas múltiples circunstancias locales engendran como climas particulares, por así decir, dentro de los generales. 
$1^{\circ}$ Casanare-San Martin (los Llanos). - Integramente pertenecen a la zona tórrida, con el año por mitad repartido en estaciones seca y lluviosa. Al pie de la serranía el clima es esencialmente anormal, por refrescarlo con exceso, a la madrugada, los vientos fríos que descienden de las cimas nevadas. En el centro de la llanura poco baja el termómetro a media noche; pero en cambio, a medio día en verano hasta se duplica la temperatura al rayo del sol $\left(62^{\circ}\right)$, lo que mata a los extraños que afrontan ese calor sin srandes precauciones. Entonces. a la excesiva sequedad del aire $\left(56^{\circ}\right)$ se agrega el humo del incendio de los pajonales, lo que hace casi irrespirable esa atmósfera de fuego. En las mesas, menos húmedas y mejor ventiladas y por consiguiente en San Martín, el clima es relativamen. te sano $y$ fresco. La mayor temperatura media en la llanura, la de $35^{\circ}$, está fuera de Colombia, en Caicara, que es el infierno de la región.

La estación seca abarca de diciembre a marzo, época en que el cielo permanece despejaclo, no se oye un trueno y soplan las brisas del NE. y ENE., violentas a medio día, nulas durante la noche y que en vez de refrescar, aumentan el bochorno con sus bocanadas de fuego. Las lluvias principian en abril, tienen dos máximos en julio y noviembre y un mí. nimum hacia septiembre. La máxima inundación, por desborde de los ríos, acaece en agosto. Las sa. banas dan paso peligroso en junio y diciembre; en enero ya está enjuta la llanura.

$2^{\circ}$ Caquetá (Amazonia). - Caracteriza el clima de esta zona una excesiva humedad; de ordinario el cielo se muestra nebuloso y con frecuencia caen chaparrones en el verano. Como en el Llano, la temperatura del medio clía, al sol, es irresistible. La porción más fresca $y$ sana es el valle mismo del Amazonas, frecuentemente velado por densa bruma en la mañana; la zona más ardiente y malsana está en la parte central de la hoya del río Caquetá $\left(37^{\circ}\right)$, donde es fama enferma todo el que en ella permanece algunos días: mejor clima se encuentra sobre el Putumayo y el Vaupés. Las lluvias son casi continuas de abril a septiembre, con máximum en junio; en verano llueve con frecuen. cia, especialmente en diciembre.

$3^{\circ} \mathrm{El}$ Chocó. - Esta región, sobre todo en su parte alta, es única por su clima en el Nuevo Mundo. En la porción central de la parte alta se mantiene el termómetro a $30^{\circ}$, en tanto que en la baja y donde llegan las brisas del mar sólo sube a $27^{\circ}$; en la mesa, en los valles altos $y$ en los trozos máximos de Baudó, apenas alcanza a $21^{\circ}$. De ordinario el clima se refresca a la madrugada con la brisa de la montaña. Lo característico del clima del Chocó (como en el Caquetá) es la humedad, puesto que en lo más fuerte de lo que puede llamarse estación seca, el higrómetro marca $90^{\circ}$ y por lo tanto allí se vive en un perenne baño de vapor que humedece la ropa $y$ debilita el organismo. En invierno, de los ríos, lagumas $y$ pantanos se ven salir nubes de vapores que el viento empuja contra la cordillera, y luego, tras un momento de calma sofocante, se lesatan en lluvia cuando el sol pasa por el cenit, para reproducirse el fenómeno en la tarde $\mathbf{y}$ provocar un segundo aguacero, que de ordinario dura hasta la madrugada. Por lo común llueve menos en enero y febrero y más de noviembre a mayo en la cordillera, $y$ de marzo a junio en las partes bajas. En los contornos del golfo de Urabá, merced a la acción del alisio, hay verano real de enero a marzo.

$4^{\circ}$ La región atlántica. - Por su área considerable comprende porciones en las cuales el clima presenta sus diferencias. El Sinú se asemeja en algo a la hoya del Atrato $y$ es zona de enlace entre ésta y los Montes de María. Al otro extremo (el del E.) se tiende la península goajira, árida, inculta, donde el viento leranta remolinos de arena por ser en extremo seca, pues apenas caen algunos aguaceros de septiembre a noviembre, $\mathbf{y}$ al rayo del sol sube el termómetro a $67^{\circ}$. En puridad de verdad. respecto de clima la Goajira es una porción de las fronterizas $y$ venezolanas tierras de Coro, con las cuales constituye un grupo especial, del todo diferente de los circunvecinos. En la cuenca de Maracaibo, que demora al $\mathbf{S}$. de la anterior, ya el invierno dura de mayo a octubre, sin que falten aguaceros en el resto del año, en especial hacia la confluencia del Zulia $\boldsymbol{y}$ el Catatumbo, por lo húmedo del suelo $y$ por las grandes masas de vapores que produce el lago, verdadero polo de atracción atmosférica, y que el alisio empuja hacia las selvas del mediodía, en las que por la noche cruza el aire luz fatua a modo de fanal que a intervalos ilumina el paisaje. A juzgar por los datos recogidos, es también aquí donde se verifica la mayor precipitación húmeda de América, como que excede de 5 metros, por lo cual la comarca es un verdadero sunderbund, gran laboratorio de miasmas y donde a la vez se halla una de las porciones menos sanas del país. En los anchos valles que se abren sobre esa selva (Cúcuta, Ocaña), hay puntos donde es común ver el termómetro a $38^{\circ}$ a la sombra, y bajar hasta $18^{\circ}$ al amanecer. Más arriba, en los valles de la serranía. el clima es delicioso pero enervante. En fin, en las cimas de las cordilleras del marco de la cuenca se hallan quizá los páramos más bravos del país, de ordinario lluviosos $y$ engendradores de frecuentes y fortísimas tormentas. Desde el punto de vista higrométrico, Cúcuta es una excepción inexplicable, pues forma una mancha de aspecto goajiro donde la lluvia no alcanza a 2 metros en el año.

El Valle de Upar, o sea el cañón abierto entre la Sierra Nevada de Santa Marta $\mathbf{y}$ los Andes, tiene un clima muy análogo al de Casanare, $y$ como al ardiente sol del medio día siguen las frescas brisas que en la tarde bajan de la nevada, el clima es nocivo para el pecho. Hacia el sur, o sea sobre la laguna de Zapatosa, suele reinar una calma sofocante. Las lluvias caen de abril a octubre $\mathbf{y}$ por la 
putrefacción de los vegetales en el plato de Zapatosa, con el principio del verano aparecen, como en todo el país, las llamadas calenturas de Navidad. En esta región se producen igualmente las fiebres de Chiriguaná, miradas como la ultramanifestación del paludismo en Colombia.

En las llanuras de Bolivar, por las condiciones geográficas y topográficas de la comarca, en realidad, como en el Llano, llueve seis meses en el año; con todo, hacia fines de Junio, el veranito llamado de San Juan, a veces bastante prolongado, separa mejor las dos estaciones lluviosas trimestrales, que en caso contrario se confunden en una. En los valles cálidos y montuosos de la parte alta de los ríos San Jorge y Sinú, el invierno suele durar hasta nueve meses. En las llanuras bajas, muy húmedas, especialmente reinan las fibres palúdicas en septiembre y octubre. En las lomas arenáceas de la comarca, en verano, el calor suele hacerse insoportable aun para los naturales de ellas. Hacia las costas del norte suelen caer unas lluvias llamadas nortes, que no pasan del litoral y ocurren particularmente en noviembre $\mathrm{y}$ diciembre. En las lomas de María y de Tubará es notable el frío de la noche y abundantísima la niebla de la madrugada.

Cuanto al valle mismo del bajo Magdalena, donde llueve en los meses de abril a diciembre, las barrancas altas del río son sanas y las refresca la brisa de éste, análoga al terral de la Costa; no sucede lo mismo en las fajas pantanosas que median entre ellas y las sabanas altas. El río crece un poco en mayo-junio y mucho más en septiembre-diciembre, tornándose peligrosa su navegación para las barcas cuando soplan los temporales huracanados del Sinú, que se presentan en especial en agosto, mes casi de verano en Chiriguaná. En el bajo Cauca los vientos húmedos del sur producen molestísimas lloviznas. Aquí, en invierno el cielo se mantiene bromizo, lo que no sucede en las sabanas altas, y la inundación remeda a Casanare, con su quieta y extensísima laguna. En el Magdalena central es más largo y fuerte el invierno, como que es una zona de transición en la que no escampa sino de diciembre a febrero. Aqui, en la margen derecha, no sólo existe otro de los infiernos colombianos $\left(38^{\circ}\right)$, sino que, según todas las apariencias, se encuentra también el territorio más insalubre de Colombia, en las vecindades del bajo Sogamoso.

$5^{\circ}$ Valle del Tolima (alto Magdalena). - Esta región, por su configuración topográfica, por las arenáceas llanuras del thalweg, las altísimas cordilleras que la rodean y las especies de boquetes que la enlazan a la Costa y al Caqueta, presenta la suma y compendio de todos los climas y estaciones, por más que en ella aparezcan las dos épocas de lluvia y las dos de sequía engendradas por la marcha anual del sol. La temperatura del fondo decrece regularmente de $\mathrm{N}$. a $\mathbf{S}$., pero en la mitad $\mathrm{N}$., en verano, el termómetro sube a $34^{\circ}$ y $36^{\circ}$ en los llanos áridos, después de medio día, y al rayo del sol el calor alcanza proporciones inauditas. En la mitad sur baja a $23^{\circ}$, pero a causa de los nevados vecinos hay allí lugares, como San Agustín, donde casi de repente varía la temperatura de 23 a $9^{\circ}$. Hacia el centro, sobre la línea Saldaña-Bogotá, el choque de los vientos del $\mathrm{N}$. y del $\mathrm{S}$. origina violentos temporales, abundantes en descargas eléctricas. La segunda estación lluviosa de septiembre a diciembre es más regular que la primera, que en el centro suele limitarse a los meses de abril y mayo, en tanto que en el S. se extiende hasta junio y aún a julio en las serranías de los Pardaos.

$6^{\circ}$ La mesa oriental. - Por lo extenso y complejo de su relieve, esta región abarca numerosas subdivisiones de clima, que rasgos acentuados diferencian unas de otras. $A l \mathrm{~N}$., en el fondo del Pilar de Labateca, a pesar de su escasa altitud, la temperatura media sólo llega a $17^{\circ}$, debido a los yermos páramos que la envuelven: en la hoz de Margua el choque de los vientos produce violentos temporales que duran hasta seis días; $y$ en la Mesa de Juan Rodrígnez el páramo de ordinario está envuelto por densa niebla o batido por recios aguaceros. La zona del Lebrija es algo así como de transición entre las vecinas, aun cuando en ella prevalecen los cálidos vientos del Magdalena. Más al sur, en las tierras de Guanentá, es rasgo característico el cañón del Sube - donde en verano alcanza el termómetro a $38^{\circ}$ - que crea dos como corrientes de fuego que suben por los cañones del Chicamocha $y$ el Saravita casi hasta su principio, puesto que allí marca entonces el termómetro $24^{\circ}$. En el te. rritorio envuelto por esa herradura de ardientes grietas, el clima oscila en el año entre 20 y $30^{\circ}$, según las localidades, tiene dos épocas de lluvia, $y$ hacia el centro guarda ma especie de polo tempestuoso (Mogotes), por la convergencia de los vientos fríos de los páramos del contorno. En los valles de Vélez y de Leiva, por la abundancia de vientos húmedos, hay cumbres (Gámbita) donde apenas se suspende la lluvia en diciembre-febrero, bien que en julio $\mathbf{v}$ agosto prevalecen destempladas lloviznas que enfrían bastante el fondo de las cuencas, como sucede en Leiva.

Al contrario, en las tierras intermedias entre el cañón del Chicamocha, la Sierra Nevada de Chita y la Mesa Colorada, uno de los páramos más fríos 5 tempestuosos del país $\left(4^{\circ}-0^{\circ}\right)$, se producen complicaciones singulares, puesto que en Capitanejo varía el termómetro de 14 a $30^{\circ}$. Al pie de dicha Sierra Nevada el invierno se prolonga bastante, $\mathbf{y}$ de ahí hacia el sur, según los valles, su entrada se atrasa o adelanta hasta un mes. Cuanto a la altiplanicie de Tundama, en el fondo el clima oscila

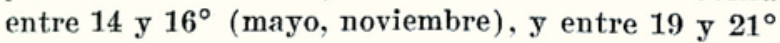
(diciembre-febrero), cuando en las terrazas que están al pie del muro de la cuenca apenas cambia de 12 a $15^{\circ}$. Semejantes son las tierras de la cuen. ce de Fúquene, cuyo fondo es algo más tibio. 
En las cuencas que constituyen la banda oriental de la mesa, al respaldo de las altiplanicies, la tem. peratura del fondo varía de 25 a $31^{\circ} y$ el invierno mucho es más largo en las partes más bajas. En las partes altas hay valles, como el de Boyacá, donde el viento de junio $y$ julio es tan seco y frío, que el termómetro desciende a $S^{\circ} y$ en invierno, a par que se duplica la temperatura, se hace tan húmeda la atmósfera, que dentro de las casas se revienen el azúcar y la panela. En la opuesta banda, o sea en los valles occidentales, a igual altitud, la temperatura es mucho mayor, debido a las influencias del valle del Tolima, las épocas de lluvia sufren retardos o adelantos de conformidad con la orientación de sus hoces, $y$ en los páramos del E., en especial en la cuencal de $\mathrm{Muzo}$ (verano $30-32^{\circ}$ ), hay boquerones donde precisamente sopla viento huracanado a medio día. En la cañada que sigue al Salto de Tequendama la lumedad ambiente es más considerable y más nocivo el clima por las transiciones consecuenciales de tal desproporción. El tibio valle de Fusaga. sugrá es el que menos se diferencia en estaciones de la Sabana de Bogotá, cuyo clima, sin duda ninguma, debe tomarse como el típico de las altiplanicies. En el centro de la llanura la temperatura es algo menor que en los abrigados valles que se abren sobre ella y lo mismo sucede si se comparan sus mitades occidental y oriental, o sur y norte; en un grado supera Hatoviejo a Soacha, que está a un

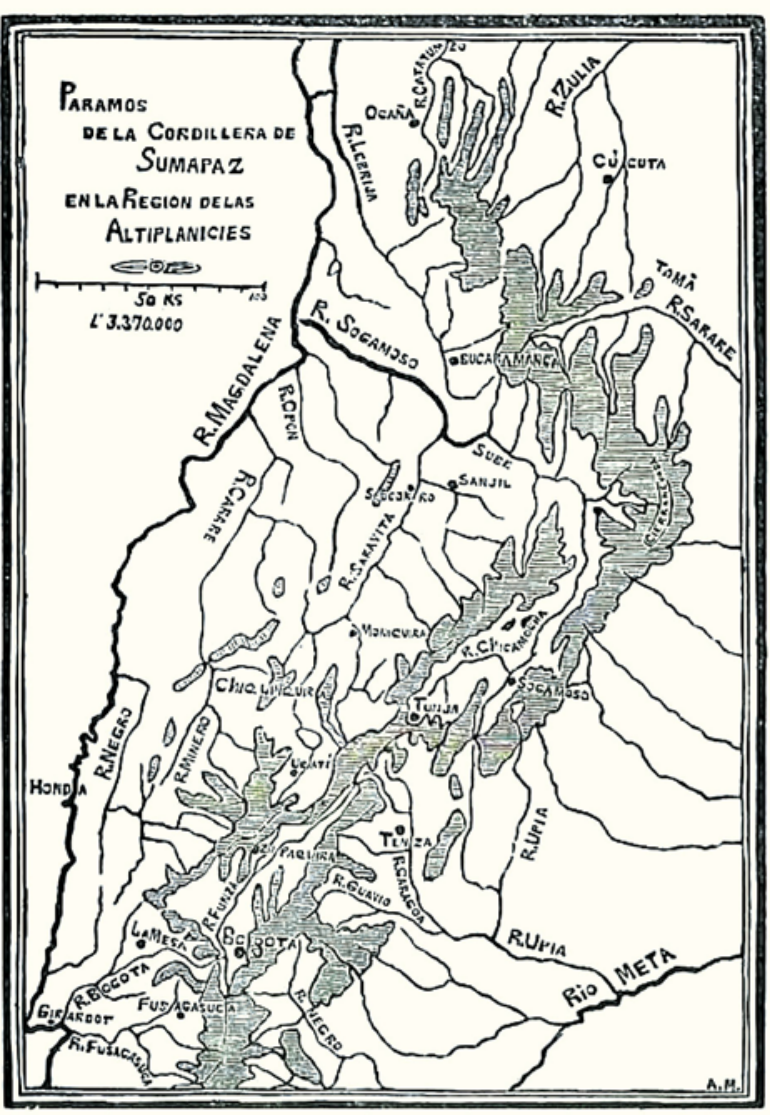

Ejes de las cumbres en la región central de la cordillera de Sumapaz. hectómetro menos de altitud. La humedad media no es excesiva $\left(65^{\circ}\right)$ y la temperatura anual no varía sino dentro de límites muy reducidos, de acuerdo con las épocas de lluvia y sequía; no sucede lo mismo con la diurna, que entraña una verdadera marea termométrica, con $10^{\circ}$ en la mañana y la noche y 18 y aun 21 a medio día. Al amanecer es común que el termómetro baje a $0^{\circ}$ en enero $\mathbf{y}$ agosto, lo que produce fuertes $y$ perjudiciales heladas, que algunas veces solidifican la superficie de las lagunas. El alisio del SE. sopla principalmente de junio a agosto con gran fuerza $\mathbf{y}$ trae destempladas lloviznas. En los otros meses reina el del NE. (noviembre), o bien soplan vientos locales, en especial en diciembre $y$ febrero, en que se establece el del SW. por la abra del Tequendama. Las lluvias no son uniformes en la Sabana, puesto que en el valle de Chocontá se asemejan más a las de Casanare, o sea duran de marzo a noviembre, con intensidad máxima en mayo y junio. En el centro de la llanura cae menor cantidad de agua, y son más marcadas las dos épocas de invierno (marzomayo, septiembre-noviembre) y las dos de verano y de aquéllas es más regular la segunda, en la cual cae por lo menos tanta agua como en las dos es. taciones secas, en las que no faltan aguaceros. En un período de diez años la cantidad de lluvia caida varió de un mínimo de 85 centímetros a $1,40 \mathrm{~m}$. o sea casi de uno a dos, lo cual explica las vicisitudes de la agricultura en torno de la capital.

$\gamma^{\circ}$ El macizo antioqueño. - Como la Antioquia propiamente dicha levanta su maciza mole entre un grupo de nevados y dos ardientes valles, semeja una especie de península estriada en su centro por cálido surco. Por esto la acrópolis antioqueña, la mesa de Santa Rosa, resulta con clima que no dice con su altitud, pues no siendo ésta sino de 2.600 a 2.500 , el termómetro apenas sube de 9 a $12^{\circ}$, es decir, marca un verdadero páramo. Alli la lluvia es intensa, frecuente el granizo y el cielo nebuloso $y$ en las cumbres de Santa Inés, que al pie tienen cañones de $30^{\circ}$ en verano, los temporales alcanzan inauditas proporciones. En el valle bajo del Nechí (verano 29 a $35^{\circ}$ ), muy fresco por la noche, reinan fiebres que poco desdicen de las de Chiriguaná. Al S. de Santa Rosa se tienden el templado valle de Medellín $\left(20\right.$ a $\left.22^{\circ}\right)$ y el más extenso y frío de Rionegro (1S a $20^{\circ}$ ); en aquél prevalecen las influencias atmosféricas del bajo Canca y en éste las del Magdalena central, por lo cual es más húmedo. El cañón del Cauca se distingue por lo intenso de la temperatura de su fondo y lo fuerte de los vientos que lo azotan. La tierra de Arma se reduce a una serie de cajones $\sin$ ventilación, ardientes y malsanos en su remate, húmedos y destemplados en su origen. Las lluvias son considerables en ẽstas hondonadas que por las tardes son bañadas por vientos fastidiosos que bajan de las alturas.

El valle del Cauca. - De Popayán a Cartago desciende la temperatura que allá es primaveral 


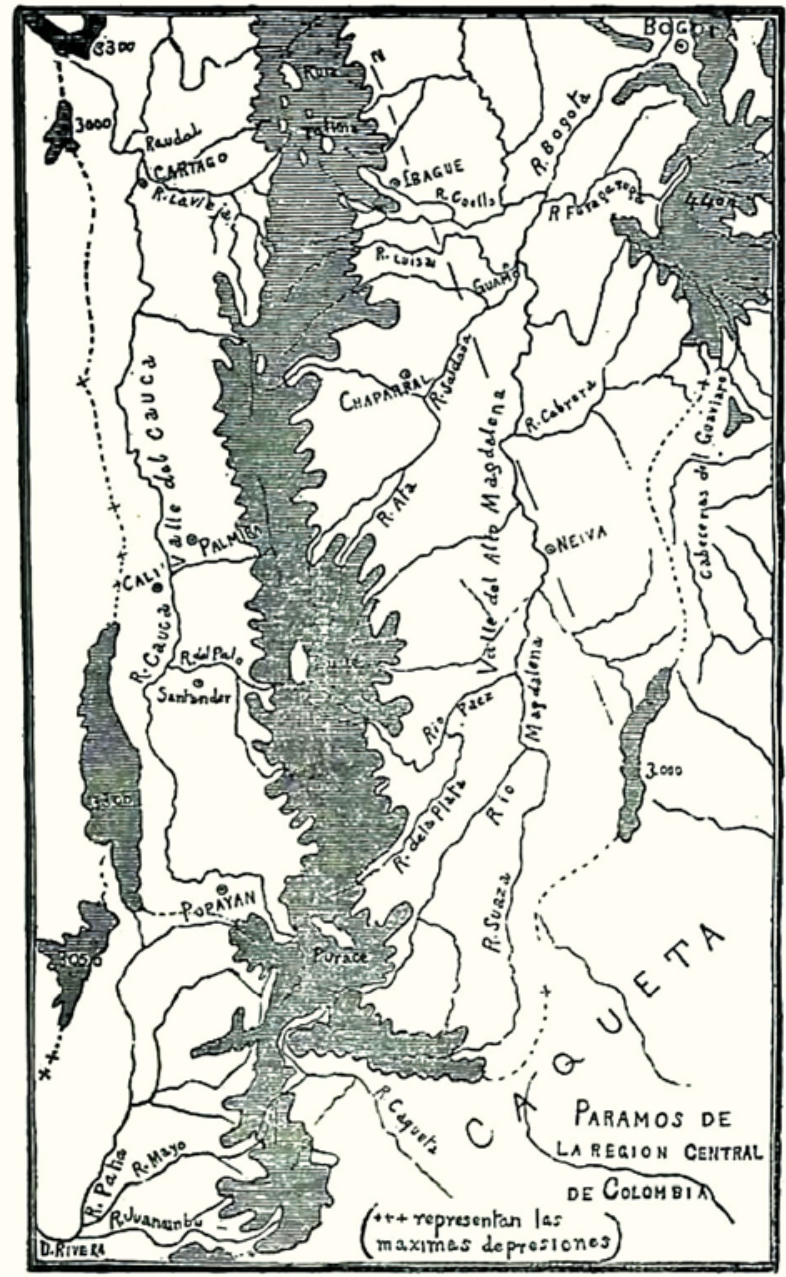

Parameras y cresterías de la parte central de la región andina.

$\left(17\right.$ a $\left.21^{\circ}\right)$ y acá es templada y tórrida $\left(22\right.$ a $\left.29^{\circ}\right)$, un poco más fresca hacia la cintura de Buga, y algo más ardiente en el centro de las dos cuencas que separa esa estrechura. Es más cálida y seca la banda occidental (verano 30 a $32^{\circ}$ ), más húmeda y malsana la oriental, y como vientos alternan los dos alisios, con variaciones locales e inversas a las que se observan en el valle del Tolima. En las cumbres quindianas es casi continua la llovizna y soplan violentos temporales de junio a septiembre.

La región del Patía. - Esta comarca, que ocupa todo el extremo sur de la mesa occidental, comprende una serie de tierras paramosas estriadas por cañones que convergen hacia la ardiente y malsana llanura del Patía $\left(29^{\circ}\right)$, que hacia la hoz de $\mathrm{Mi}$. namá encierra uno de los infiernos colombianos. Tal es la acción que ejerce este receptáculo, que hacia el $\mathrm{N}$. y el S. las temperaturas cálidas y templadas avanzan hasta el Roble y hasta Puerres, o sea marcan un surco o grieta cálida que, incluso el valle del Cauca, puede decirse casi sin exageración va de la frontera ecuatoriana al mar Caribe y une las diversas porciones que constituyen la gran mesa occidental. En el fondo de la depresion patiana el termómetro al medio día marca $38^{\circ}$ a la sombra y $50^{\circ}$ al rayo del sol, cuando en Túquerres indica $3^{\circ}$ y a $25^{\circ}$, respectivamente, por lo cual es insoportable el clima y los páramos circunvecinos yacen envueltos en niebla o cubiertos de granizo. Las lluvias son aquí más intensas: en Túquerres se presentan primero de mitad de enero a mayo y luego de septiembre a mitad de diciembre; en la depresión patiana llueve más, pero en menos tiempo.

$8^{\circ}$ Panamá. - El clima de esta zona es esencial. mente marítimo y presenta marcalos contrastes entre sus dos vertientes; la temperatura es más uniforme en el litoral caribe y la cima de la cordillera mucho más fría de lo que normalmente corresponde a su mediana altitud. La temperatura oscila entre 22 y $35^{\circ}$, lo que en muchos puntos la hace sofocante en verano y desagradable en invierno. En las selvas del Darién, sobre ser intensa la precipitación hú. meda anual, no es raro que se concentre en corto tiempo, pues de ordinario la sexta parte cae en un solo mes (noviembre) y de ella nu cuarto en un solo día! De ordinario, no hay sino un aguacero corto al ponerse el sol. En lugares como Portobelo, truena todo el año. En cambio, el Istmo guarda sitios como Chorrera, reputado como el mejor sa. natorium del país y los valles de David, tipo de las regiones tropicales de eterna primavera.

\section{FLORA Y FAUNA}

Cada región del globo posee una fauna (conjunto de especies animales) y una flora (conjunto de es. pecies vegetales) determinalas, es decir, que aparece caracterizada por una cierta asociación de es. pecies animales y de especies vegetales. El número de especies puede ser considerable $y$ sin embargo no comprender cada una sino un pequeño número de individuos: fauna $\mathrm{y}$ flora son entonces ricas, pero la vegetación será poco densa y los animales esca. sos; y al contrario: la Amazonia, por ejemplo, tiene una vegetación riquísima $y$ al mismo tiempo una flora muy variada; no sucede lo mismo en los Llanos, a pesar de ser exuberante la vegetación. La humedad, el suelo y sobre todo el calor deciden de la repartición de las floras y faunas sobre el globo, por lo cual los botánicos dividen la vegetación en tres grupos: boreal, tropical y austral, compren. diendo el segundo dos floras: la paleotropical (antiguo continente) y la neotropical (América), en la cual se incluye Colombia. Por su parte los zoólo. gos dividen la tierra en seis regiones: la paleártica (norte del antiguo continente), la neártica (América del Norte), la oriental, la etiópica, la neotropical (América Central y Meridional) y la austra. liana. La región neotropical comprende los grupos mexicano (América Central), antillano, colombiano (con Ecuador), brasilero $\mathrm{y}$ argentino (1).

(1) Las cartas y croquis referentes a esta seccion, lo mismo que las relaclonadas con el clima, los cultivos y los yacimientos de minerales, se encontrarán en el libro destinado especlalmen. te al estudio de las riquezas naturales del pais. 
a) Flora. - Nacen los regetales amoldándose al medio ambiente, por lo cual, según sea la naturaleza, altura y situación del terreno y la distribución que en él resulten del calor y la humedad, así también será la flora de una comarca en cuanto a su aspecto, su savia y su carácter. Por esto y por las condiciones generales elimatéricas del globo, dominan en él tres tipos de vegetación caraceterísticos: el frío endurece la tierra, a la que sólo deja producir musgos, líquenes, arbustos achaparrados y pequeñas gramíneas; el calor la viste con estupenda, monstruosa vegetación, en que dominan la palmera y el baobab; el término medio entre los dos favorece la aparición de ricas mieses y praderas. A lo dicho debe agregarse que en las costas la onda salobre $y$ las arenas producen flora peculiar, vecina de la varia y matizada del océano y de las yerbas y juncales que orlan a los ríos. También trae consigo sus diferencias la montaña, cuyo tinte $y$ cuyo aspecto difieren siempre del que muestra la llamura.

Por eso Colombia, alzada a un tiempo entre el ecuador $y$ el polo $y$ entre el ecuador y el trópico, guarda vegetales de toda especie; mas, como la mayor parte de su suelo es cálido, es también esta la flora que domina en el país, surgiendo de entre ella, como de entre gentil $\mathbf{y}$ aromado búcaro, el vario ramillete con que se engalanan las montañas, en cuyo tope, como remate del maravilloso ramo, brillan perdurables al sol riquísimos diamantes. Poco es, sin duda, el campo que nuestro suelo ofrece a la flora extratropical, la que por lo mismo, dada la actual distribución de los habitantes, reviste no. table importancia; luégo veremos cómo ella se es.

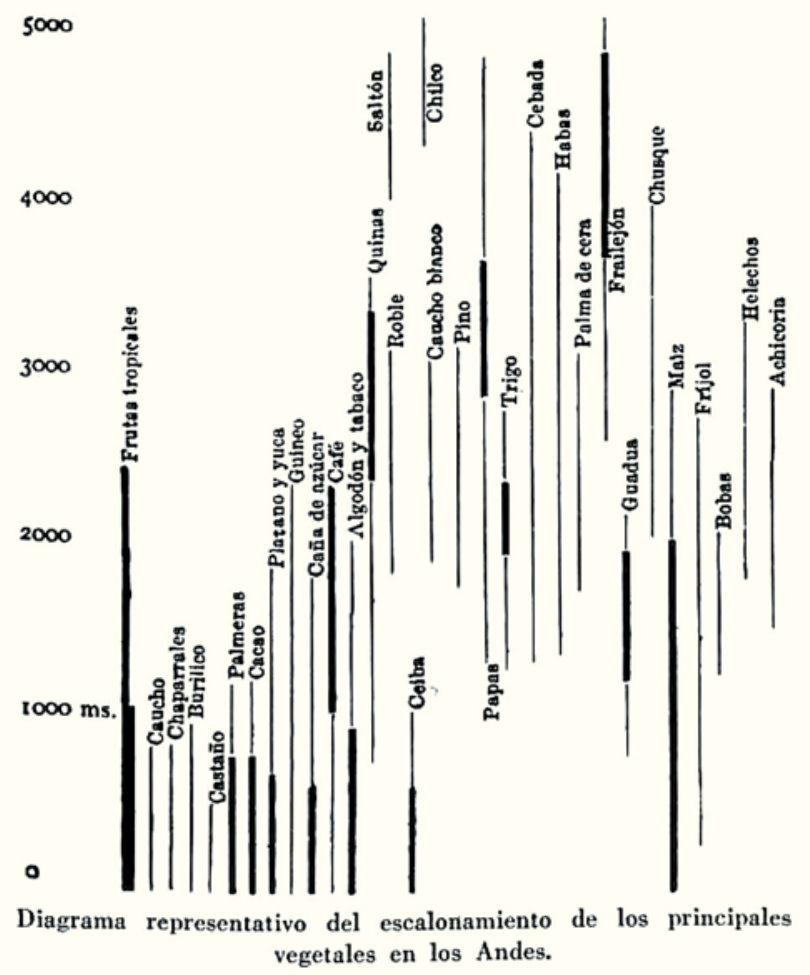

calona en las gigantes faldas para pasar de las palunas y musáceas al café $\mathbf{y}$ el trigo, a la papa $\mathbf{y}$ el maíz y la cebada, simpática gramínea que desafía el hielo de los páramos, en donde el frailejón ofrece siempre calor al aterido viajero. Como se comprende, es flora de transición la que cubre la falda media de los montes y en la llanura, según sea la humedad de ésta, constante o accidental, domina la selva o la graminea.

También las divisiones naturales del territorio patrio concuerdan con lo que hay que decir de la flora. En efecto, en el Darién, el Chocó, el Magdalena central, el bajo Cauca y el Caquetá, impera la selva, la selva con tipo propio en cada zona, virgen de ordinario, pues sólo como oasis naturales o artificiales varía alli la vegetación; en los Llanos y las sabanas de Bolívar $\mathrm{y}$ del alto Magdalena, dominan las gramíneas, bien que con sus variantes en el aspecto del conjunto; en el Valle de Upar y la Goajira hállase suelo sahárico, con cactus, espinos $\mathrm{y}$ arenales; los valles andinos se cubren con galanas flores, con jugosa yerba las altiplanicies, con áspera paja y raquíticas plantas las altivas cumbres. A primera vista, entre la flora de las dos grandes mesas no hay diferencia alguna; pero bien estudiado el punto, se la halla, $y$ notable, conforme lo veremos en su lugar.

Una de las magnificencias de nuestra patria es la inmensa selva virgen, cuya salvaje belleza no olvida quien la vio una vez, $\mathbf{y}$ la que en aspecto, a primera vista, no se distingue de la del norte sino por la magnitud de los árboles, el verde más brillante de sus hojas y la riqueza y variedad de sus bejucos que bajo el cielo de los tropicos tornan el paisaje grave $\mathbf{y}$ austero. Sin embargo, al recorrerla, no hay en ella la monotonía de aquélla; las más diversas familias mezclan allí sus ramas, cada árbol of rece aspecto propio, $\mathbf{y}$ las formas, pulimento, color de tronco y hojas, por su infinita variedad, semejan singular kaleidoscopio, merced al diversísimo matiz de las hermosas flores que, ora sueltas, ora en guirnaldas, esmaltan con su pedrería aquel poético conjunto que perfuman con su aroma. En el Chocó pre. domina por el exceso de humedad la vegetación criptogámica y vascular; en el Caquetá y el Magdalena el bejuco que se enlaza a los árboles, los une con festones que semejan elegantes pórticos y de tal modo traba la copa de aquéllos, que a sus pies jamás llega el rayo del sol; de ordinario bajo aquella bóveda, entre los gigantes que la sostienen, cre. cen arbustillos y orquídeas que forman como digno tapiz de esos edificios, interrumpido a trecho por las aguas quietas, las que por su abundancia dan alguna frescura al conjunto que bulle con los mil ruidos de la más vigorosa de las manifestaciones de la vida orgánica del planeta. En las faldas de los montes hay selvas en que faltan los bejucos y la vegetación menuda: alls los ‘árboles crecen solos, mezclan sus copas, en el suelo tienen por tapiz sus marchitas hojas que apagan todo ruido y el bosque 


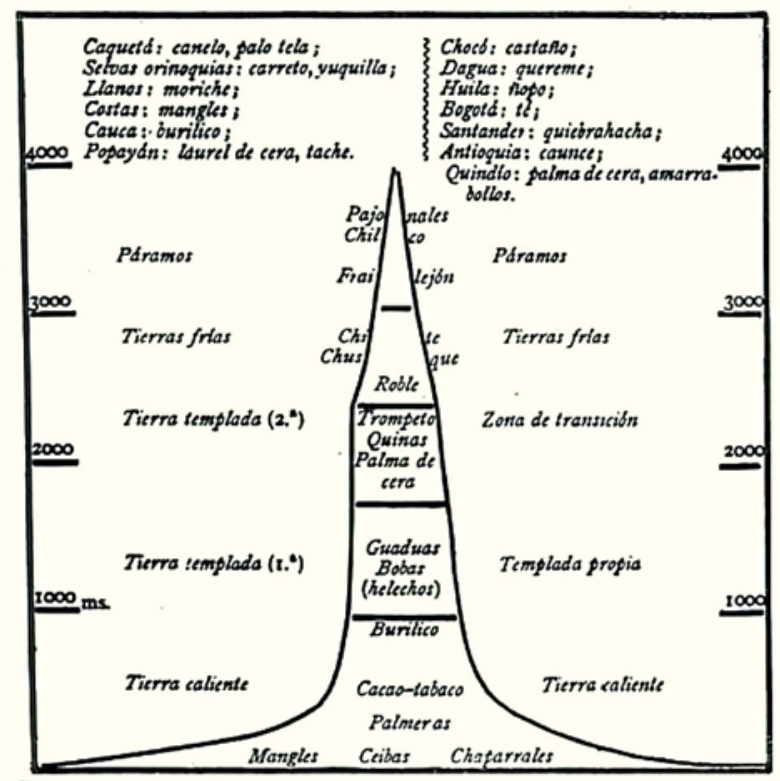

Diagrama del escalonamiento altimétrico de la flora colombiana.

semeja naves colosales y sombrías, negras en lontananza, donde el pecho tiembla al recorrer tan sin igual paisaje, dominado por algo misterioso, imposible de expresar... Otra existe en que los árboles, a modo de mangles de tierra firme, no sólo unen las copas, sino que enlazan las raíces, cuando no los troncos, resultando el más singular de los te. jidos que idearse puede. Hacia las cumbres la selva se empequeñece sin dejar de ser ristosa, rica en aromáticos bejucos y elegantes helechos, su verde es más negro, y por último se transforma en arbolillos sueltos y miserables. Del invierno al verano, nuestra selva, que sólo varía con la humedad, apenas se diferencia en el verde más o menos claro de sus hojas, en la riqueza del follaje, en la intensidad del matiz de las flores, siempre maravilloso en el trópico. Unicamente hacia el Valle de Upar es tal la sequedad, que ni la selva puede ser tupida, ni el verano la deja con follaje. En fin, también se diferencia de la base a la cumbre de las montañas, pues en éstas, antes de las rocas desnudas y las gramíneas amargas y fibrosas unidas al frailejón, ya los árboles son medianos o pequeños, con tronco corto, atezado, retorcido, muy dividido en ramas con hojas lustrosas, duras, coriáceas, como hechas para absorber y resistir la fría humedad de las parame ras. En resumen, la montaña en cada zona ayuda a dar a éstas su típico carácter.

A par de la selva con sus mil matices dominan también en nuestra patria las zonas herbáceas, de ordinario planas, bien que alcancen ignalmente las alturas, aunque sin la majestad y autonomía que en aquéllas. En tesis general, su aspecto tiene algo de semejante, pero varía también, como la selva, de una a otra zona. En efecto, en la Goajira dominan cactus y arbustos espinosos que a trechos dejan ver la desnuda arena; en Chiriguaná, a las altas gra. míneas se unen dondequiera los agaves y escasean los árboles, más abundantes en las sabanas de Bo. lívar; en el Tolima, ora el suelo apenas se alcanza a cubrir con diminutas gramíneas, ora éstas son crecidas y mientras en unos puntos predominan los arbustos espinosos, en otros, grandes matorrales y frondosas ceibas forman setos naturales; similar es tanto la vistosa llanura caucana como la del Patía. Las llanuras de las altas montañas muestran sus verdes gramíneas esmaltadas de-flores, en especial por las de la característica achicoria, y los pantanos del litoral se adornan con manglares. En la llanura herbácea por excelencia, en los Llanos, aqui y allá se alzan grupos de elegantes palmeras o sur. gen bosquecillos de hoja dura, sombrío para los ganados, en lo cual son inferiores al moriche, que guarda frescura y cuyo bello abanico contrasta con el siempre gris y polvoriento de la melancólica Cobija. Esto al terminar el invierno, porque en ve. rano los tintes amarillos de las muertas hojas imprimen especialísimo aspecto a los paisajes.

b) Fauna. - Bien que sujetos a la acción del clima, los animales dependen mucho menos de su influencia en las áreas que ocupan, de donde mayor extensión y lindes menos precisos en las provincias zoológicas. Sin embargo, como aquella influencia nunca desaparece del todo, resulta que la fauna colombiana presenta poco más o menos las mismas divisiones que la flora, en especial marcadas si se trata de las tierras cálidas y frías, bien que muchas veces de una a otra zona apenas se diferencien las especies en la talla o el matiz de la piel o la pluma; tenemos, pues, ante todo, dos divisiones profundas: la fauna andina y la de las tierras calientes. La última pertenece integramente a lo que los zoólogos llaman región neotropical, caracterizada por los monos de nariz lateral, los murciélagos de compleja hoja nasal, los grandes roedores subungulados, los marsupiales, los felinos subordinados y otros animales, que si en general son inferiores a los del

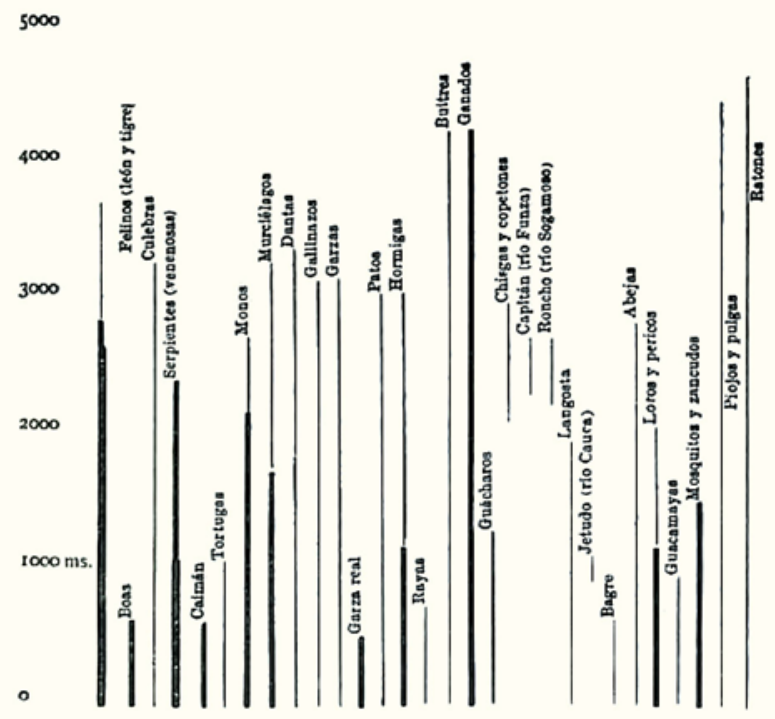

Diagrama representativo del escalonamiento de algunos animales en los Andes. 
Viejo Mundo en magnitud, de ordinario les superan en gracia, variedad $y$ hermosura. La primera, que puede englobarse en la neártica, ofrece marcada inferioridad en sus tipos, salvo alguna excepción, y son varios los animales que en ambas mesas les dan vida propia. Cesa la vida con la nieve y sin embargo sobre ella se remonta el único animal que, si bien vive en las altas montañas, busca su presa lo mismo en la llanura ardiente que en la yerma paramera y da así enlace a toda la fauna del país: nos referimos al cóndor, con justicia elegido para figurar en las armas de Colombia, puesto que es en la parte sur de la cresta del Quindío en donde alcanza su mayor bravura y desarrollo; algo más de 6 metros de envergadura medía la pareja que uno de nuestros virreyes envió a España. Por lo demás, y esto se comprende bien, ningún país de América rivaliza con el nuestro en la riqueza de la fauna, como ninguno le iguala en la flora; nuestro grande oriente encierra a un tiempo los animales de Venezuela, Guayana y el Brasil; los Andes del sur guardan los del Ecuador; Panamá, los de Cen. tro América; la costa atlántica, algunos de los de las Antillas y el Choc6, y las montañas interiores forman provincias completamente diversas de aquéllas $y$ por lo tanto propias (1).

(1) "La subregión brasilense es la más vasta de todas las neotropicales, como que se extiende del Atlantico a los Andes, comprende las hoyas del Orínoco $y$ el Amazonas, $y$ no se detiene sino en el río de La Plata. Abarca un territorio formado por llanuras bajas, selvosas, a menudo inundadas, La fauna de esta región está caracterizada especialmente por los monos. las zarigüeyas, los edentados, los tapires $y$ las ratas espinosas. Muchos géneros de aves están confinados a esta comarca, siendo en las riberas del Amazonas donde esta fauna ornitológica exhibe toda su belleza". - A. F. Brehm. 